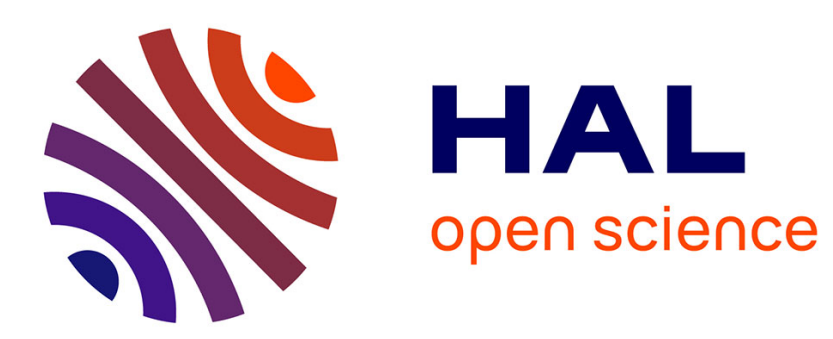

\title{
Partial substitution of Mo6+ by S6+ in the fast oxide ion conductor La2Mo2O9: Synthesis, structure and sulfur depletion
}

\author{
Noureddine Mhadhbi, Gwenaël Corbel, P. Lacorre, Alain Bulou
}

\section{To cite this version:}

Noureddine Mhadhbi, Gwenaël Corbel, P. Lacorre, Alain Bulou. Partial substitution of Mo6+ by S6+ in the fast oxide ion conductor La2Mo2O9: Synthesis, structure and sulfur depletion. Journal of Solid State Chemistry, 2012, 190, pp.246-256. 10.1016/j.jssc.2012.02.043 . hal-02189604

\section{HAL Id: hal-02189604 https://hal.science/hal-02189604}

Submitted on 19 Jul 2019

HAL is a multi-disciplinary open access archive for the deposit and dissemination of scientific research documents, whether they are published or not. The documents may come from teaching and research institutions in France or abroad, or from public or private research centers.
L'archive ouverte pluridisciplinaire HAL, est destinée au dépôt et à la diffusion de documents scientifiques de niveau recherche, publiés ou non, émanant des établissements d'enseignement et de recherche français ou étrangers, des laboratoires publics ou privés. 


\title{
Partial substitution of $\mathrm{Mo}^{6+}$ by $\mathrm{S}^{6+}$ in the fast oxide ion conductor $\mathrm{La}_{2} \mathrm{Mo}_{2} \mathrm{O}_{9}$ : Synthesis, structure and sulfur depletion
}

\author{
Noureddine Mhadhbi, Gwenaël Corbel*, Philippe Lacorre, Alain Bulou \\ LUNAM Université, Université du Maine, CNRS UMR 6283, Institut des Molécules et des Matériaux du Mans, \\ Avenue Olivier Messiaen, 72085 Le Mans Cedex 9, France
}

\begin{abstract}
Powder-solid state reaction route using $\mathrm{La}_{2}\left(\mathrm{SO}_{4}\right)_{3}$ as sulfur source was used to prepare compositions of the solid solution $\mathrm{La}_{2} \mathrm{Mo}_{2}-y \mathrm{~S}_{y} \mathrm{O}_{9}$. Single phases were only obtained in the substitution range extending up to $y=0.8(40 \mathrm{~mol} \% \mathrm{~S})$ at the annealing temperature of $850^{\circ} \mathrm{C}$ with regard to the limit of stability of the lanthanum sulphate reactant. Within the synthesis conditions, a stabilization of the high temperature $\beta$-form is observed from and above $y=0.1$ ( $5 \mathrm{~mol} \% \mathrm{~S}$ ). Temperature-controlled $\mathrm{X}$-ray diffraction and thermogravimetric analyses have shown that $\mathrm{La}_{2} \mathrm{Mo}_{2-y} \mathrm{~S}_{y} \mathrm{O}_{9}$ raw powders undergo thermal decompositions in two steps. Heating above $900{ }^{\circ} \mathrm{C}$, a sulfur depletion to the benefit of molybdenum in $\mathrm{La}_{2} \mathrm{Mo}_{2}-y \mathrm{~S}_{y} \mathrm{O}_{9}$ raw powders leads to the formation of $\mathrm{La}_{2} \mathrm{SO}_{6}$. At higher temperature, the exsolved $\mathrm{La}_{2} \mathrm{SO}_{6}$ phase then decomposes into $\mathrm{La}_{2} \mathrm{O}_{3}$, which in turn reacts with the sulfur-depleted $\mathrm{La}_{2} \mathrm{Mo}_{2} \mathrm{O}_{9}$ phase to form $\mathrm{La}_{2} \mathrm{MoO}_{6}$. The present study also reveals that depending on the substitution rate $y$, the sulfur depletion can be induced by ball-milling of raw powders. Along the $\mathrm{La}_{2} \mathrm{Mo}_{2} \mathrm{y}_{y} \mathrm{O}_{9}$ series, the isovalent substitution of molybdenum by sulfur tends to restrict in magnitude, or even to suppress above $400^{\circ} \mathrm{C}$, the distortive thermal expansion of the cubic $\beta$-type structure, thus strongly decreasing the conductance at high temperature.
\end{abstract}

\section{Keywords}

LAMOX, X-ray diffraction, Ionic conductivity, Thermal decomposition

\section{Introduction}

Fast oxide ion conductors are of considerable interest for "clean" electrochemical applications including solid oxide fuel cells, oxygen sensors and oxygen separation membranes. In this field, Lacorre et al. have discovered 11 years ago a novel oxide ion conductor $\mathrm{La}_{2} \mathrm{Mo}_{2} \mathrm{O}_{9}$ $[1,2]$. This binary oxide exhibits, above a first order and reversible $\alpha$ (monoclinic, $P 2_{1}$ ) to $\beta$ (cubic, $P 2_{1} 3$ ) structural phase transition at $580^{\circ} \mathrm{C}$, an anionic conductivity higher $\left(5 \times 10^{-2} \mathrm{~S} \mathrm{~cm}^{-1}\right.$ at $\left.700{ }^{\circ} \mathrm{C}\right)$ than that of the conventional $8 \mathrm{~mol} \%$ yttria stabilized zirconia SOFC electrolyte. Therefore, the strategy was to stabilize the high- $T$ anionically disordered cubic $\boldsymbol{\beta}$-form through solid solution formation in order to preserve the oxide ion conductivity at lower temperatures. Thus, several derivatives of $\mathrm{La}_{2} \mathrm{Mo}_{2} \mathrm{O}_{9}$ have been studied, substituting:

- either $\mathrm{Bi}^{3+}[3], \mathrm{Pr}^{3+}[4], \mathrm{Nd}^{3+}[5,6], \mathrm{Eu}^{3+}[7], \mathrm{Gd}^{3+}[5], \mathrm{Y}^{3+}$ [5], $\mathrm{Na}^{+}[8], \mathrm{K}^{+}[8,9], \mathrm{Rb}^{+}[8], \mathrm{Ca}^{2+}[10], \mathrm{Sr}^{2+}[10], \mathrm{Ba}^{2+}[10]$ for $\mathrm{La}^{3+}$

- or $\mathrm{Cr}^{6+}[11], \mathrm{W}^{6+}[11,12], \mathrm{V}^{5+}[13], \mathrm{Nb}^{5+}[14,15], \mathrm{Ta}^{5+}[15]$ for $\mathrm{Mo}^{6+}$.

Apart from $\mathrm{Pr}^{3+}, \mathrm{Na}^{+}$and $\mathrm{Nb}^{5+}$, most substitutes for La or Mo in $\mathrm{La}_{2} \mathrm{Mo}_{2} \mathrm{O}_{9}$ stabilize, above certain content, the cubic $\beta$-form at room

* Corresponding author. Fax: +3324383 3506

E-mail address: gwenael.corbel@univ-lemans.fr (G. Corbel). temperature. We explored the properties of LAMOX compounds partially substituted by $\mathrm{K}^{+}$(4-6 mol\% [16]), $\mathrm{Ca}^{2+}$ (3-4 mol\% $[17,18]), \mathrm{Ba}^{2+}(7.5-10 \mathrm{~mol} \%[16]), \mathrm{Nd}^{3+}\left(20-60 \mathrm{~mol} \%\right.$ [19]), $\mathrm{Eu}^{3+}$ (7.5-10 mol\% [20]). A release of topological metastability upon heating (successive $\beta$-metastable/ $\alpha$ and $\alpha / \beta$ transitions in the temperature range $460-500{ }^{\circ} \mathrm{C}$ and at around $570{ }^{\circ} \mathrm{C}$, respectively) sometimes combined with partial exsolution and recombination processes were observed by temperature-controlled X-ray diffraction. These thorough studies of the structural instabilities provide key information in understanding either the transient decrease of the conductivity in limited thermal range or its irreversible decrease with time at high temperature.

Except for a quick limited survey (two compositions $\beta$ $\mathrm{La}_{2} \mathrm{Mo}_{1.6} \mathrm{~S}_{0.4} \mathrm{O}_{9}$ and $\beta-\mathrm{La}_{2} \mathrm{MoSO}_{9}$ ) [21] in the early years after the discovery of $\mathrm{La}_{2} \mathrm{Mo}_{2} \mathrm{O}_{9}$-based oxide-ion conductors, no thorough study of the solid solution $\mathrm{La}_{2} \mathrm{Mo}_{2-y} \mathrm{~S}_{y} \mathrm{O}_{9}$ had been undertaken yet. The motivation for the present investigation was at first to determine the extent of the solid solution and then to obtain a better insight into the influence of sulfur on the crystal structure, the thermal stability and the electrical properties.

\section{Experimental section}

\section{Synthesis}

Two grams of polycrystalline samples of $\beta-\mathrm{La}_{2} \mathrm{Mo}_{2-y} \mathrm{~S}_{y} \mathrm{O}_{9}(y=0.1$, $0.2,0.3,0.4,0.5,0.6,0.8,1)$ were prepared by conventional solid state 
reaction from elementary oxides $\mathrm{La}_{2} \mathrm{O}_{3}$ (REacton ${ }^{\circledR}$ 99.9\% from Alfa Aesar), $\mathrm{La}_{2}\left(\mathrm{SO}_{4}\right)_{3} \cdot 9 \mathrm{H}_{2} \mathrm{O}$ (99.999\% from Aldrich) and $\mathrm{MoO}_{3}$ (PURATREM $^{\circledR}$ 99.999\% from Strem Chemicals). Prior to use, $\mathrm{La}_{2} \mathrm{O}_{3}$ was calcinated in air for $12 \mathrm{~h}$ at $1000{ }^{\circ} \mathrm{C}$ in order to remove adsorbed water and carbon dioxide. Reactant powders were stoichiometrically weighted, thoroughly ground in an agate mortar and at first heated in an alumina crucible at $500{ }^{\circ} \mathrm{C}$ for $12 \mathrm{~h}$ (heating and cooling rates of $\left.2{ }^{\circ} \mathrm{C} / \mathrm{min}\right)$. It is noteworthy that the reactant $\mathrm{La}_{2}\left(\mathrm{SO}_{4}\right)_{3} \cdot 9 \mathrm{H}_{2} \mathrm{O}$ is completely dehydrated at $350{ }^{\circ} \mathrm{C}$ and starts decomposing in air into the oxysulfate $\mathrm{La}_{2} \mathrm{SO}_{6}$ above $890{ }^{\circ} \mathrm{C}$ [22] with a release of sulfur dioxide and dioxygen gas. In order to prevent the decomposition of $\mathrm{La}_{2}\left(\mathrm{SO}_{4}\right)_{3}$, several intermediate stages of heating for $12 \mathrm{~h}$ and regrinding were performed from and above $600{ }^{\circ} \mathrm{C}$ by step increment of $50{ }^{\circ} \mathrm{C}$ up to get pure samples. Single $\beta$-phases were finally obtained after firing at $850{ }^{\circ} \mathrm{C}$ and cooling down to room temperature at $5{ }^{\circ} \mathrm{C} /$ $\min$.

\section{Ball-milling and sintering}

Raw powder samples of $\beta-\mathrm{La}_{2} \mathrm{Mo}_{2}-y \mathrm{~S}_{y} \mathrm{O}_{9}(y=0.1,0.2,0.3,0.4$, $0.5,0.6$ ) were ball-milled (FRITSCH planetary micromill pulverisette 7 apparatus with $900 \mathrm{mg}$ of sample placed into $45 \mathrm{~cm}^{3}$ agate bowl with six $10 \mathrm{~mm}$ diameter agate balls and covered with ethanol) for four alternations of $15 \mathrm{~min}$ milling sequences at $700 \mathrm{rpm}$ with $15 \mathrm{~min}$ pause in between. The ball-milled powder with an added drop of polyvinyl alcohol solution $\left(\left(\mathrm{C}_{2} \mathrm{H}_{4} \mathrm{O}\right)_{n}\right.$ in water solution) was dried at $100{ }^{\circ} \mathrm{C}$, shaped as a pellet $(\approx 13 \mathrm{~mm}$ in diameter and $\approx 0.8 \mathrm{~mm}$ in thickness or $\approx 5 \mathrm{~mm}$ in diameter and $\approx 3-5 \mathrm{~mm}$ in thickness) in a uniaxial hydraulic press. The pellet was at first annealed at $400{ }^{\circ} \mathrm{C}$ for $12 \mathrm{~h}$ to decompose the organic bender and was finally sintered at $850{ }^{\circ} \mathrm{C}$ for $12 \mathrm{~h}$ (heating/cooling rates of $5{ }^{\circ} \mathrm{C} / \mathrm{min}$ ).

\section{Structural characterization}

\section{Raw powders}

The phase purity of raw powders was checked by recording $\mathrm{X}$-ray powder diffraction patterns at room temperature on a PANalytical $\theta / \theta$ Bragg-Brentano X'pert MPD PRO diffractometer $\left(\mathrm{CuK \alpha} \alpha_{1+2}\right.$ radiations) equipped with the X'Celerator multi-elements detector. In order to determine the lattice expansion of powdered sample with the temperature, the X-ray diffractograms were collected under air flow from room temperature (RT) to $845^{\circ} \mathrm{C}$ (heating rate of $10{ }^{\circ} \mathrm{C} / \mathrm{min}$, temperature stabilization for 20 min with temperature correction after calibration [23]) on the same diffractometer equipped with an HTK 1200 Anton Paar furnace using an $\mathrm{Al}_{2} \mathrm{O}_{3}$ sample holder cup. The diffractograms were collected at and above room temperature in the [9-130 scattering angle range with a $0.0167^{\circ}$ step for a total acquisition time of $193 \mathrm{~min}$. Unit cell parameters have been obtained from the diffraction pattern fitting by the Le Bail method [24] using the program FullProf [25]. The study of the stability of raw powder under isothermal annealing at $900{ }^{\circ} \mathrm{C}$ (heating rate of $10^{\circ} \mathrm{C} / \mathrm{min}$ ) was carried out on $\beta-\mathrm{La}_{2} \mathrm{Mo}_{1.7} \mathrm{~S}_{0.3} \mathrm{O}_{9}$ and $\beta-\mathrm{La}_{2} \mathrm{Mo}_{1.4} \mathrm{~S}_{0.6} \mathrm{O}_{9}$ samples by in situ $\mathrm{X}$-ray diffraction. The raw sample was continuously scanned in terms of successive periods of $20 \mathrm{~min}$ for $14 \mathrm{~h} 40$. Each scan was performed in the $\left[10-60^{\circ}\right]$ scattering angle range with a $0.0167^{\circ}$ step.

\section{Ball-milled powders and sintered pellets}

In order to check the phase purity of ball-milled powders, diffractograms were recorded during $260 \mathrm{~min}$ with a $0.0084^{\circ}$ step in the $\left[27-32^{\circ}\right]$ scattering angle range where the most intense diffraction peaks of the decomposition products $\mathrm{La}_{2} \mathrm{MoO}_{6}$ or $\mathrm{La}_{2} \mathrm{SO}_{6}$ are located. A study of the thermal stability of sintered pellets ( $\approx 13 \mathrm{~mm}$ in diameter and $\approx 0.8 \mathrm{~mm}$ in thickness) was carried out by collecting every $25{ }^{\circ} \mathrm{C}$ upon heating from RT to $845^{\circ} \mathrm{C}$ (heating rate of $10{ }^{\circ} \mathrm{C} / \mathrm{min}$, temperature stabilization for $20 \mathrm{~min}$ ), diffractograms in the $\left[10-60^{\circ}\right]$ scattering angle range over 20 min with a $0.0167^{\circ}$ step.

\section{Thermal analyses}

Thermogravimetric (TG) and Differential Thermal (DT) Analyses were performed on $\sim 95-100 \mathrm{mg}$ raw powder samples with a TGA/DTA Q600 SDT TA Instruments apparatus (Pt crucibles, $\alpha$ $\mathrm{Al}_{2} \mathrm{O}_{3}$ as a reference) under air flow $(100 \mathrm{~mL} / \mathrm{min})$ in the RT$1400{ }^{\circ} \mathrm{C}$ range (heating/cooling rates of $10^{\circ} \mathrm{C} / \mathrm{min}$ ).

\section{Transport property}

Thin Pt films electrodes were deposited by RF sputtering on both flat faces of sintered pellet. Conductivity was measured by using a classical symmetric two-electrodes electrochemical cell connected to a Solartron 1296 dielectric interface and a Solartron 1260 frequency response analyser. Complex impedance spectra were recorded over the $10 \mathrm{MHz}$ to $0.05 \mathrm{~Hz}$ range (AC signal amplitude of $50 \mathrm{mV}, 40$ points/decade) under dry air flow every $20{ }^{\circ} \mathrm{C}$ (thermal equilibration for $35 \mathrm{~min}$ ) at increasing temperature from 300 to $720^{\circ} \mathrm{C}$.

\section{IR spectroscopy}

Infrared transmission spectra were collected in air on polycrystalline samples with an Alpha Bruker Fourier transform infrared (FT-IR) spectrometer equipped with the "Platinum" QuickSnap $^{\mathrm{TM}}$ ATR sampling module. Each spectrum was obtained after 24 scans in the $4000-400 \mathrm{~cm}^{-1}$ range with a spectral resolution of $4 \mathrm{~cm}^{-1}$. A reference IR spectrum was collected with an empty cell and subtracted to spectra collected on specimens in order to remove the contribution of atmospheric water vapor.

\section{Results and discussion}

\section{Partial solid solution}

Within the synthesis conditions described in the experimental section, the X-ray diffraction patterns of $\mathrm{La}_{2} \mathrm{Mo}_{2-y} \mathrm{~S}_{y} \mathrm{O}_{9}$ raw powders show pure phases up to $y=0.8$ (Fig. 1). For $y \geq 0.1$, these patterns exhibit neither $2 \times 3 \times 4$ superstructure peaks at low $2 \theta$ scattering angle nor peak splitting, both characteristic of the monoclinic distortion of the low temperature $\alpha-\mathrm{La}_{2} \mathrm{Mo}_{2} \mathrm{O}_{9}$ type (Fig. 1). It indicates that a stabilization of the high temperature $\beta$ form is already achieved when $5 \mathrm{~mol} \%(y=0.1)$ of molybdenum is substituted with sulfur. The evolution of the unit cell volume with the sulfur content $y$, displayed in Fig. 2, has been obtained from Le Bail refinements [24] of the diffraction patterns in a cubic cell with the space group $P 2{ }_{1} 3$ (no. 198). Hexavalent sulfur (ionic radii $=0.12 \AA(\mathrm{CN}=4), 0.29 \AA(\mathrm{CN}=6)[26])$ being much smaller than hexavalent molybdenum (ionic radii $=0.41 \AA(\mathrm{CN}=4), 0.50 \AA$ $(\mathrm{CN}=5), 0.59 \AA(\mathrm{CN}=6)[26])$ whatever the coordination number, the unit cell volume decreases upon substitution with a linear dependence on $y$ in the range 0.1-0.6, thus following the usual Vegard's law (Fig. 2). Composition $y=0.8$ shows a slight deviation from Vegard's law despite its seemingly purity.

Attempts to further extend the solid solution within the previous synthesis conditions were carried out. For $y=1$, impurity peaks of very small intensity in the $2 \theta$ range $\left[27-32^{\circ}\right]$ remain present in addition to diffraction lines of a major $\beta-\mathrm{La}_{2} \mathrm{Mo}_{2} \mathrm{O}_{9}-$ type phase after annealings carried out at 800,825 or $850{ }^{\circ} \mathrm{C}$ for 


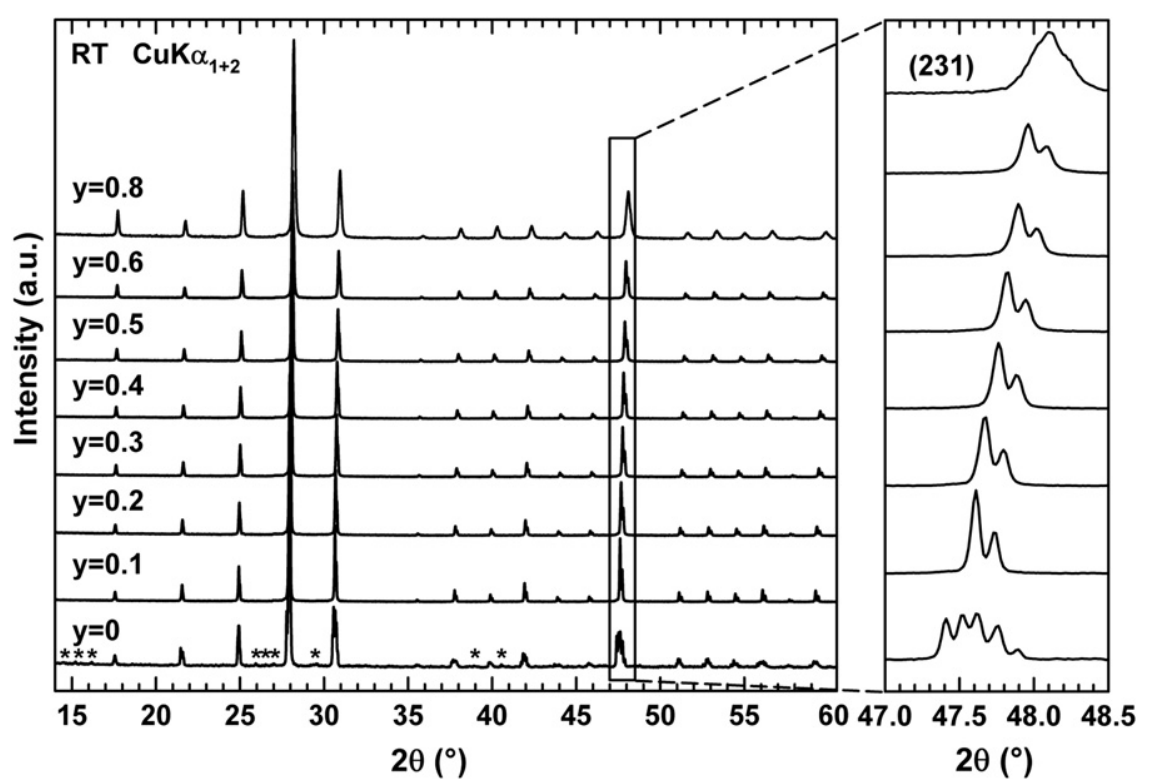

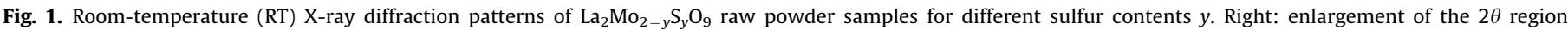
showing the absence, for $y \geq 0.1$, of the splitting of the cubic (231) peak and of superstructure peaks (*) characteristic of the monoclinic low temperature $\alpha$ form.

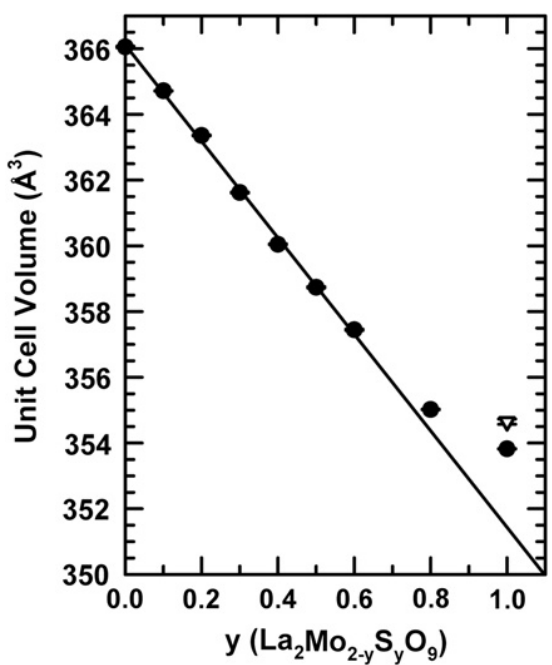

Fig. 2. Variation of the single unit cell volume with the sulfur content $y$ of $\mathrm{La}_{2} \mathrm{Mo}_{2-y} \mathrm{~S}_{y} \mathrm{O}_{9}$ raw powder samples. The two values representative of the $y=1$ composition correspond to two samples prepared at different final annealing temperatures $850^{\circ} \mathrm{C}$ (circle) and $800{ }^{\circ} \mathrm{C}$ (open triangle, extracted from Ref. [21]). Error bars are approximately the size of the data points.

$12 \mathrm{~h}$ each. The increase of the temperature up to $875^{\circ} \mathrm{C}$ leads to a significant rise of their intensity. The impurity peaks for the composition $y=1$ have a good match with a $\mathrm{La}_{2} \mathrm{SO}_{6}$ type phase (PDF no. 01-085-1535 [27]). When compared with the diffraction patterns of lightly sulfur-substituted LAMOX phases, a severe line broadening is noticed for the two $y=0.8$ (Fig. 1) and $y=1$ compositions without any evidence for superstructure peaks at low $2 \theta$ scattering angles. The presence of this oxysulfate could originate either from a fraction of the reactant $\mathrm{La}_{2}\left(\mathrm{SO}_{4}\right)_{3}$ in excess with respect to the substitution limit, which decomposes into $\mathrm{La}_{2} \mathrm{SO}_{6}$, or from the thermal decomposition of the LAMOX phase itself. In the first case, one can expect to detect, in the diffraction pattern of the $y=1$ composition, the trace of a ternary phase with a $\mathrm{La} /(\mathrm{Mo}, \mathrm{S})$ ratio greater than unity to balance for any lanthanum excess. The absence of a third phase means that the oxysulfate $\mathrm{La}_{2} \mathrm{SO}_{6}$ comes from the decomposition of the sulfur-substituted LAMOX phase. The mechanism for exsolution of the oxysulfate

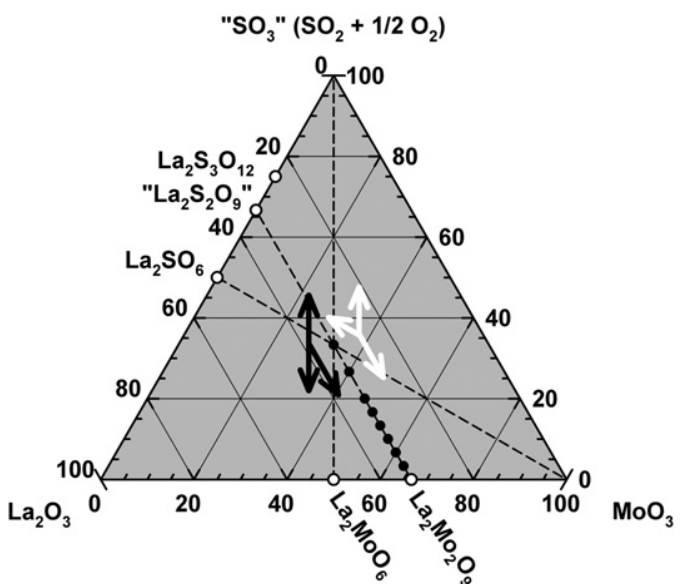

Fig. 3. Phase localization in the $\mathrm{La}_{2} \mathrm{O}_{3}-\mathrm{MoO}_{3}-$ " $\mathrm{SO}_{3}$ " ternary phase diagram (solid circles $=\mathrm{La}_{2} \mathrm{Mo}_{2-y} \mathrm{~S}_{y} \mathrm{O}_{9}$ phases and open circles = binary phases). White and black arrows correspond to the exsolution path at low temperature and to the total thermal decomposition path at high temperature, respectively.

implies the enrichment in molybdenum of the LAMOX phase to balance the sulfur depletion, according to the $\mathrm{La}_{2} \mathrm{O}_{3}-\mathrm{MoO}_{3}-$ " $\mathrm{SO}_{3}$ " ternary phase diagram in Fig. 3 (white arrows correspond to the exsolution path). The equation for the exsolution reaction is the following:

$\mathrm{La}_{2} \mathrm{Mo}_{2-y} \mathrm{~S}_{y} \mathrm{O}_{9} \rightarrow(1-z) \mathrm{La}_{2} \mathrm{Mo}_{2-y+x} \mathrm{~S}_{y-x} \mathrm{O}_{9}+z \mathrm{La}_{2} \mathrm{SO}_{6}+z \mathrm{SO}_{2}$ $+1 / 2 z \mathrm{O}_{2}$

with $z=x /(2-y+x)$

The release of sulfur dioxide is the driving force for the segregation of the $\mathrm{La}_{2} \mathrm{SO}_{6}$ phase at surface of LAMOX grains. For $\beta$ - $\mathrm{La}_{2} \mathrm{Mo}_{2-y} \mathrm{~S}_{y} \mathrm{O}_{9}$ raw powders and $\mathrm{La}_{2} \mathrm{SO}_{6}$, stretching vibrations of tetrahedral $\mathrm{SO}_{4}^{2-}$ ions are revealed in the infrared spectra reported in Fig. 4 (IR bands of molybdate ions appear at lower wavenumbers). Since the intensity of these bands increases as the sulfur content $y$ increases, it constitutes a trace of a defect association of oxygen vacancies with the substitute S. Thereby, the exsolution of $\mathrm{La}_{2} \mathrm{SO}_{6}$ phase might be interpreted as resulting from the solid state diffusion of the sulfur-oxygen vacancy 

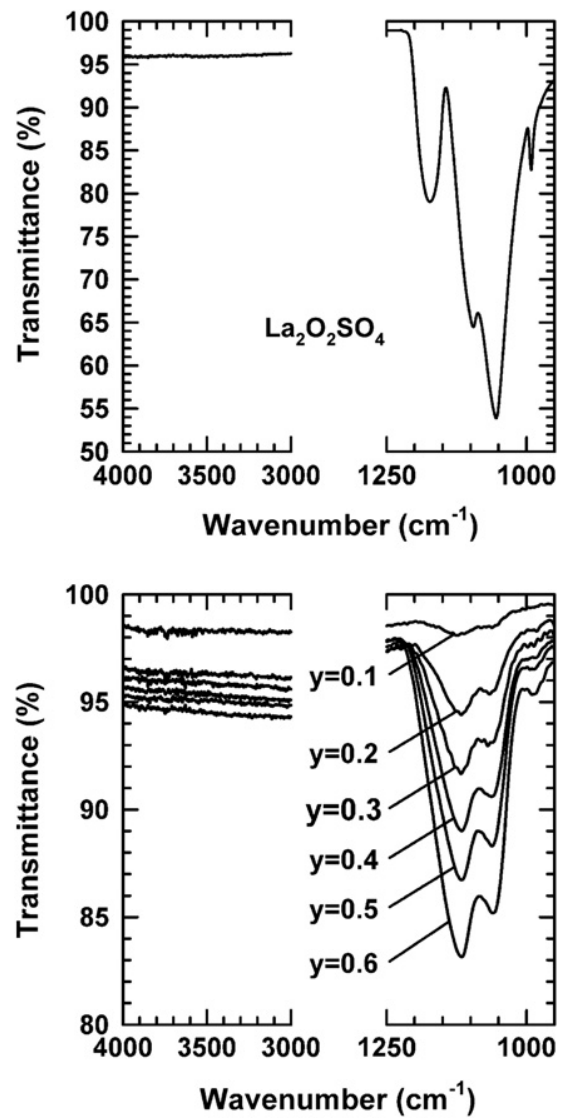

Fig. 4. Infrared spectra collected at room temperature on $\beta-\mathrm{La}_{2} \mathrm{Mo}_{2-y} \mathrm{~S}_{y} \mathrm{O}_{9}$ raw powder samples showing the bands arising from the antisymmetric $v_{3}$ and symmetric $v_{1}$ stretching vibrations of tetrahedral $\left(\mathrm{SO}_{4}\right)^{2-}$ ions in the range $1250-950 \mathrm{~cm}^{-1}$ (the vibrations of molybdate ions are out of this spectral range) together with the absence of stretching vibrations of hydroxyl $\mathrm{OH}^{-}$ions in the $4000-3000 \mathrm{~cm}^{-1}$. The infrared spectrum of the oxysulfate $\mathrm{La}_{2} \mathrm{SO}_{6}$ is added for reference.

clusters to the surface of LAMOX grains. A cross diffusion of hexavalent Mo and S cations most probably occurs from the center area to peripheral area of a grain, depleting either the peripheral or the core region in sulfur to the benefit of molybdenum. Within a grain, a concentration gradient should therefore exist. This is consistent with the broadening of diffraction lines of the LAMOX phase observed at room temperature. For the $y=1$ sample annealed at $850^{\circ} \mathrm{C}$, Le Bail fit of the diffraction pattern with a single cubic LAMOX phase was performed. The average unit cell volume of $353.82(1) \AA^{3}$, much higher than that expected from the Vegard's law for $y=1$ (Fig. 2), is consistent with a sulfur depletion. The difference in cell volume of $\approx 2.4 \AA^{3}$ between the value calculated from the Vegard's law and the experimental one would correspond to a huge depletion of $\approx 8.1 \mathrm{~mol} \% \mathrm{~S}$. Despite a lowering of the synthesis temperature down to $800^{\circ} \mathrm{C}$, the $y=1$ sample remains biphasic. When the sample is prepared at $800{ }^{\circ} \mathrm{C}$, small amount of $\mathrm{La}_{2} \mathrm{SO}_{6}$ phase is detected on X-ray diffraction pattern collected with a high counting time. Thus, contrary to what has been reported in a previous paper [21], the $y=1$ composition prepared at $800{ }^{\circ} \mathrm{C}$ was probably not pure. When compared with the unit cell volume expected from the Vegard's law for $y=1$, a depletion of one-sixth of the nominal sulfur content $(\approx 10.9 \mathrm{~mol} \%$ ) can be estimated from the experimental unit cell volume of 354.65(8) $\AA^{3}$ (open triangle in Fig. 2) tabulated in Ref. [21]. For the present $y=0.8$ composition, the line broadening, similar to that observed for $y=1$ sample, would mean that a decomposition also took place. The difference between the unit cell volume expected from the Vegard's law for $y=0.8$ and the value deduced from Le Bail fit of the diffraction pattern is much lower $\left(\approx+0.65 \AA^{3}\right)$ than that observed for $y=1$ (Fig. 2$)$. At such a small sulfur depletion ( $\approx 2.2 \mathrm{~mol} \%$ ), the weight fraction of the $\mathrm{La}_{2} \mathrm{SO}_{6}$ phase $(\approx 1.5 \mathrm{wt} \%$ ) might be lower than the detection limit of X-ray powder diffraction technique (with the data collection conditions used) which could explain why the $y=0.8$ composition is seemingly monophasic. On the other hand, Castellanos and West have proposed that positive deviation from the Vegard's law in solid solutions may indicate the presence of clusters within apparently homogeneous single phase [28]. In the present case, a tendency to sulfur clustering in a LAMOX-type structure could explain that $y=0.8$ composition is macroscopically homogeneous (no detectable $\mathrm{La}_{2} \mathrm{SO}_{6}$ impurity) and that a deviation from the Vegard's law however exists, at least in the compositional range $y=0.6-0.8$. In a random solid solution, the primary bonding forces are cation-anion attractions (i.e., the forces between nearest neighbor atoms). The tendency to cluster in a solid-solution structure depends on the forces between next nearest neighbor atoms (i.e., on cation-cation repulsions). In the $\beta-\mathrm{La}_{2} \mathrm{Mo}_{2} \mathrm{O}_{9}$ structure, the nearest neighbor cations of $\mathrm{Mo}^{6+}$ are $\mathrm{La}^{3+}$ ions. When molybdenum is substituted by an isovalent cation smaller in size as $S^{6+}$, the repulsions between nearest neighbor cations becomes stronger than it was in the parent compound $\mathrm{La}_{2} \mathrm{Mo}_{2} \mathrm{O}_{9}$ due to the shortening of the cation-cation distance. A way to minimize the $\mathrm{La}^{3+}-\mathrm{S}^{6+}$ repulsions at high sulfur content is to maximize the cation-cation distance thus slightly increases the cell volume as observed for $y=0.8$. One can consider the diffraction line broadening observed for $y=0.8$ composition as a trace of a strain effect arising from this local distortion.

Given the difficulty in the compositional range $0.6<y<1$ to obtain pure sample at lower synthesis temperature than $850{ }^{\circ} \mathrm{C}$ while keeping the nominal sulfur content, no further attempts to determine the substitution limit were undertaken. In the next sections, the influence of sulfur on the thermal stability, thermal expansion and on the transport properties will be analyzed only for compositions of the partial solid solution ranging from $y=0.1$ to 0.6 .

\section{Thermal decomposition}

As a prerequisite to study the influence of sulfur substitution on the transport properties upon heating, the thermal stability of raw powders was probed in air up to $1400^{\circ} \mathrm{C}$ by TG-DT analyses. As an example, Fig. 5a displays the thermogravimetric diagram of the $\mathrm{La}_{2} \mathrm{Mo}_{1.4} \mathrm{~S}_{0.6} \mathrm{O}_{9}$ sample. All compositions of the series exhibit a weight loss above $900{ }^{\circ} \mathrm{C}$. In Fig. 5c, one can note that the total weight loss observed for all compositions in the range $y=0.1-0.6$ increases linearly with the sulfur content $y$. At temperature higher than $1365^{\circ} \mathrm{C}$, all studied compositions start melting which prevents any post-analysis by X-ray powder diffraction of the decomposition products (solubilization being the only way to remove the sample). Then, a second TG analysis up to $1350^{\circ} \mathrm{C}$ was only performed on a $\beta$ $\mathrm{La}_{2} \mathrm{Mo}_{1.4} \mathrm{~S}_{0.6} \mathrm{O}_{9}$ sample and a diffraction pattern has been recorded on the decomposed specimen. As shown in Fig. 5b, several intense peaks fairly well matching with a $\mathrm{La}_{2} \mathrm{MoO}_{6}$-type phase (PDF no. 01-0830710 [27]) are present in addition to diffraction lines of a monoclinic $\alpha$ - $\mathrm{La}_{2} \mathrm{Mo}_{2} \mathrm{O}_{9}$-type phase (inset of Fig. $5 \mathrm{~b}$ shows the characteristic splitting of the (231) cubic line). The destabilization of the $\beta$-form originates from sulfur depletion to the benefit of molybdenum. However, no trace of a $\mathrm{La}_{2} \mathrm{SO}_{6}$-type phase was identified as a final product of the thermal decomposition of $\beta-\mathrm{La}_{2} \mathrm{Mo}_{1.4} \mathrm{~S}_{0.6} \mathrm{O}_{9}$ sample. The layered structures of $\mathrm{La}_{2} \mathrm{MoO}_{6}$ [29] and $\mathrm{La}_{2} \mathrm{SO}_{6}$ [30] are both built up from fluorite-like slabs $\left(\mathrm{La}_{2} \mathrm{O}_{2}\right)^{2+}$ alternating with single layers of isolated tetrahedra $\left[\mathrm{MO}_{4}\right]^{2-}(\mathrm{M}=\mathrm{Mo}, \mathrm{S})$ along one crystallographic axis ( $c$-axis for $\mathrm{La}_{2} \mathrm{MoO}_{6}$ and $a$-axis for $\mathrm{La}_{2} \mathrm{SO}_{6}$ ). When compared with 
a

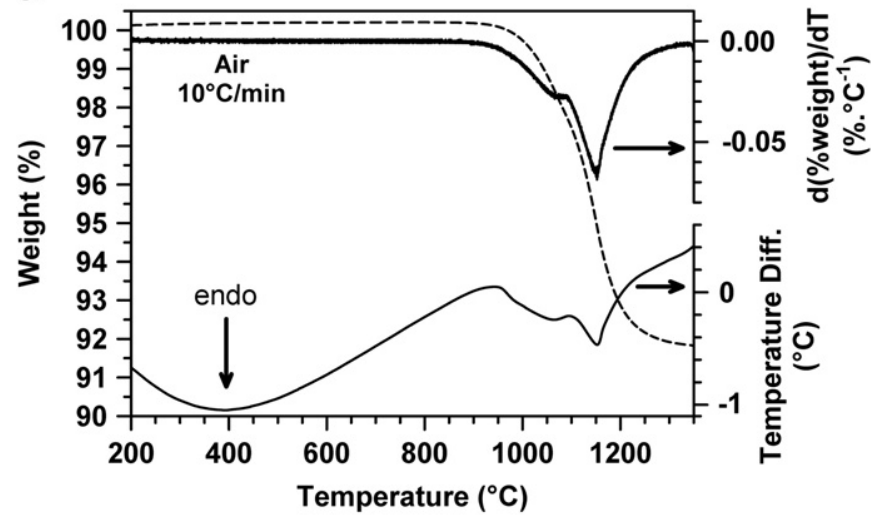

b

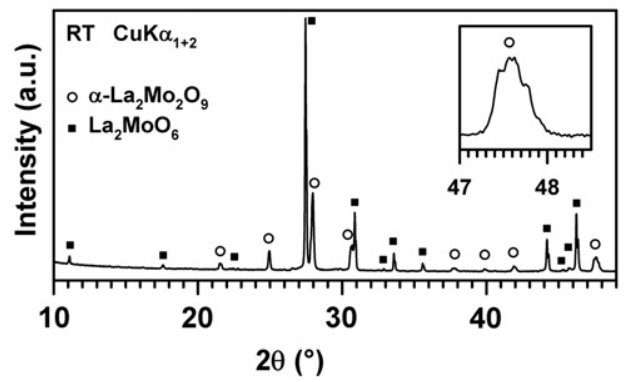

C

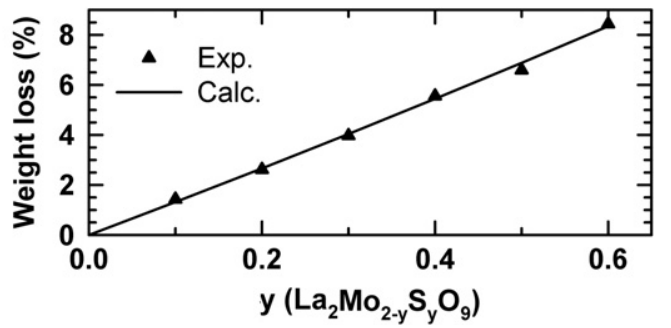

Fig. 5. (a) Thermogravimetric (dashed line) and Differential Thermal (thin solid line, bottom of the graph) diagrams upon heating in air of $\beta-\mathrm{La}_{2} \mathrm{Mo}_{1.4} \mathrm{~S}_{0.6} \mathrm{O}_{9}$ raw powder sample. The first derivative of the weight with respect to temperature is added as a thick solid line at the top of the graph. (b) Room temperature X-ray diffraction pattern recorded on the decomposed specimen. (c) Comparison between experimental and calculated (see details in the text) weight losses associated with the thermal decomposition of $\mathrm{La}_{2} \mathrm{Mo}_{2-y} \mathrm{~S}_{y} \mathrm{O}_{9}$ raw powder samples.

the tetragonal structure of $\mathrm{La}_{2} \mathrm{MoO}_{6}$, the tetrahedral sulfate anions in $\mathrm{La}_{2} \mathrm{SO}_{6}$ have a singular orientation which involves a monoclinic distortion of the cell, coupled with its half reduction along the stacking direction and its doubling within the sulfate layers. The diffraction patterns being different, the identification of the $\mathrm{La}_{2} \mathrm{MoO}_{6}-$ type phase, as a final product of the thermal decomposition of $\beta-\mathrm{La}_{2} \mathrm{Mo}_{1.4} \mathrm{~S}_{0.6} \mathrm{O}_{9}$ sample, is thereby non-ambiguous. Since the $\mathrm{La}_{2} \mathrm{Mo}_{1.9} \mathrm{~S}_{0.1} \mathrm{O}_{9}$ phase has a cubic symmetry at room temperature, the level of depletion in the $\beta-\mathrm{La}_{2} \mathrm{Mo}_{1.4} \mathrm{~S}_{0.6} \mathrm{O}_{9}$ sample should therefore be larger than $83.3 \%$ ( $25 \mathrm{~mol} \% \mathrm{~S}$ or 0.5 Sulfur per chemical formula) to explain the occurrence of a monoclinic $\alpha-\mathrm{La}_{2} \mathrm{Mo}_{2} \mathrm{O}_{9}$-type phase. Experimental weight losses were then compared to those calculated as a function of $y$ from the hypothetical equation (2) for the decomposition reaction, assuming that the final products did not contain any sulfur:

$\mathrm{La}_{2} \mathrm{Mo}_{2-y} \mathrm{~S}_{y} \mathrm{O}_{9} \rightarrow(1-y) \mathrm{La}_{2} \mathrm{Mo}_{2} \mathrm{O}_{9}+y \mathrm{La}_{2} \mathrm{MoO}_{6}+y \mathrm{SO}_{2}+1 / 2 y \mathrm{O}_{2}$

The calculated values (solid line) are reported in Fig. 5c together with experimental ones (closed triangles). The good agreement between both values clearly demonstrates that complete sulfur depletion from the LAMOX phases occurs during the thermal decomposition in the temperature range 900$1400{ }^{\circ} \mathrm{C}$. In the $\mathrm{La}_{2} \mathrm{O}_{3}-\mathrm{MoO}_{3}-$ " $\mathrm{SO}_{3}$ " ternary phase diagram shown in Fig. 3, the total decomposition path corresponds to black arrows.

In the light of what has been observed for the synthesis of the $y=1$ composition, the key step in the thermal decomposition of lightly sulfur-substituted LAMOX compounds $(y=0.1-0.6)$ could be also the exsolution of the $\mathrm{La}_{2} \mathrm{SO}_{6}$ phase. To evidence for this exsolution in compositions of the $\beta-\mathrm{La}_{2} \mathrm{Mo}_{2-y} \mathrm{~S}_{y} \mathrm{O}_{9}$ series for $y<0.6$, the effect of isothermal annealing at $900{ }^{\circ} \mathrm{C}$ on two representative members $\beta-\mathrm{La}_{2} \mathrm{Mo}_{1.7} \mathrm{~S}_{0.3} \mathrm{O}_{9}$ and $\beta-\mathrm{La}_{2} \mathrm{Mo}_{1.4} \mathrm{~S}_{0.6} \mathrm{O}_{9}$ was studied in situ by temperature-controlled X-ray diffraction. The evolution with time of X-ray diffraction patterns recorded at $900{ }^{\circ} \mathrm{C}$ for these two specimens is displayed in Fig. 6 . After $40 \mathrm{~min}$ in isothermal condition at $900{ }^{\circ} \mathrm{C}, \beta-\mathrm{La}_{2} \mathrm{Mo}_{1.4} \mathrm{~S}_{0.6} \mathrm{O}_{9}$ sample starts decomposing: several impurity peaks ascribed to a $\mathrm{La}_{2} \mathrm{SO}_{6}$ (PDF no. 01-085-1535 [27]) type phase appear and increase in intensity with the annealing time. When the sulfur depletion to the benefit of molybdenum increases with the annealing time, a progressive shift towards low scattering angles of the diffraction lines of the $\mathrm{La}_{2} \mathrm{Mo}_{2} \mathrm{O}_{9}$-type phase takes place concomitantly with the peak broadening. This is consistent with the increase of the unit cell volume when the sulfur content of the LAMOX phase decreases (or when the value of $x$ tends towards the nominal content $y$ of the LAMOX phase in Eq. (1)), as shown in Fig. 2. In $\beta$ - $\mathrm{La}_{2} \mathrm{Mo}_{1.7} \mathrm{~S}_{0.3} \mathrm{O}_{9}$, the sulfur depletion is of a lesser magnitude and starts only after a twice longer time $(80 \mathrm{~min})$ than that observed for $\beta$-La $\mathrm{La}_{1.4} \mathrm{~S}_{0.6} \mathrm{O}_{9}$ (Fig. 6). This difference in behavior might originate from the twice smaller sulfur content $y$ in the former than in the latter. The above results support the assumption that the key step, in the thermal decomposition of $\beta$ $\mathrm{La}_{2} \mathrm{Mo}_{2-y} \mathrm{~S}_{y} \mathrm{O}_{9}$ compositions, is the progressive exsolution of the $\mathrm{La}_{2} \mathrm{SO}_{6}$ phase. Since $\mathrm{La}_{2} \mathrm{SO}_{6}$ decomposes into $\mathrm{La}_{2} \mathrm{O}_{3}$ upon heating above $1100{ }^{\circ} \mathrm{C}$ [22], the as-formed lanthanum sesquioxide can in turn react with $\alpha-\mathrm{La}_{2} \mathrm{Mo}_{2} \mathrm{O}_{9}$ leading to the formation of the $\mathrm{La}_{2} \mathrm{MoO}_{6}$ phase, observed by X-ray diffraction after the full decomposition. The equations for the two steps of the decomposition reaction are the following:

$$
\begin{aligned}
& \mathrm{La}_{2} \mathrm{Mo}_{2-y} \mathrm{~S}_{y} \mathrm{O}_{9} \rightarrow\left(1-\frac{1}{2} y\right) \mathrm{La}_{2} \mathrm{Mo}_{2} \mathrm{O}_{9}+\frac{1}{2} y \mathrm{La}_{2} \mathrm{SO}_{6}+\frac{1}{2} y \mathrm{SO}_{2}+\frac{1}{4} y \mathrm{O}_{2} \\
& \left.\begin{array}{l}
\frac{1}{2} y \mathrm{La}_{2} \mathrm{SO}_{6} \rightarrow \frac{1}{2} y \mathrm{La}_{2} \mathrm{O}_{3}+\frac{1}{2} y \mathrm{SO}_{2}+\frac{1}{4} y \mathrm{O}_{2} \\
\left(1-\frac{1}{2} y\right) \mathrm{La}_{2} \mathrm{Mo}_{2} \mathrm{O}_{9}+\frac{1}{2} y \mathrm{La}_{2} \mathrm{O}_{3} \rightarrow(1-y) \mathrm{La}_{2} \mathrm{Mo}_{2} \mathrm{O}_{9}+y \mathrm{La}_{2} \mathrm{MoO}_{6}
\end{array}\right\}
\end{aligned}
$$

$$
\overline{\mathrm{La}_{2} \mathrm{Mo}_{2-y} \mathrm{~S}_{y} \mathrm{O}_{9} \rightarrow(1-y) \mathrm{La}_{2} \mathrm{Mo}_{2} \mathrm{O}_{9}+y \mathrm{La}_{2} \mathrm{MoO}_{6}+y \mathrm{SO}_{2}+\frac{1}{2} y \mathrm{O}_{2}}
$$

The presence of two peaks in the first derivative of the weight with respect to temperature for $\beta-\mathrm{La}_{2} \mathrm{Mo}_{1.4} \mathrm{~S}_{0.6} \mathrm{O}_{9}$ sample (Fig. 5a) is in good agreement with a mechanism of thermal decomposition in two stages. The second peak being narrower than the former would mean that the thermal decomposition of $\mathrm{La}_{2} \mathrm{SO}_{6}$ is faster than its exsolution from the LAMOX phase. It has been observed that the two peaks in the first derivative of the weight with respect to temperature merge in one very broad peak as the sulfur content $y$ in the LAMOX phase decreases. These two stages of decomposition are reminiscent of the way $\mathrm{La}_{2}\left(\mathrm{SO}_{4}\right)_{3}$ decomposes into $\mathrm{La}_{2} \mathrm{SO}_{6}$ and then into $\mathrm{La}_{2} \mathrm{O}_{3}[22]$.

\section{Thermal expansion versus composition}

In chemically $\beta$-stabilized LAMOX compounds, an increase of the Thermal Expansion Coefficient (TEC) is systematically observed above $\approx 400{ }^{\circ} \mathrm{C}$ [20]. Recently, the subtle structural change at the origin of this singular increase of TEC has been evidenced from a temperature-controlled neutron diffraction study of a thermodynamically stable $\beta-\mathrm{La}_{1.7} \mathrm{Bi}_{0.3} \mathrm{Mo}_{2} \mathrm{O}_{9}$ compound 

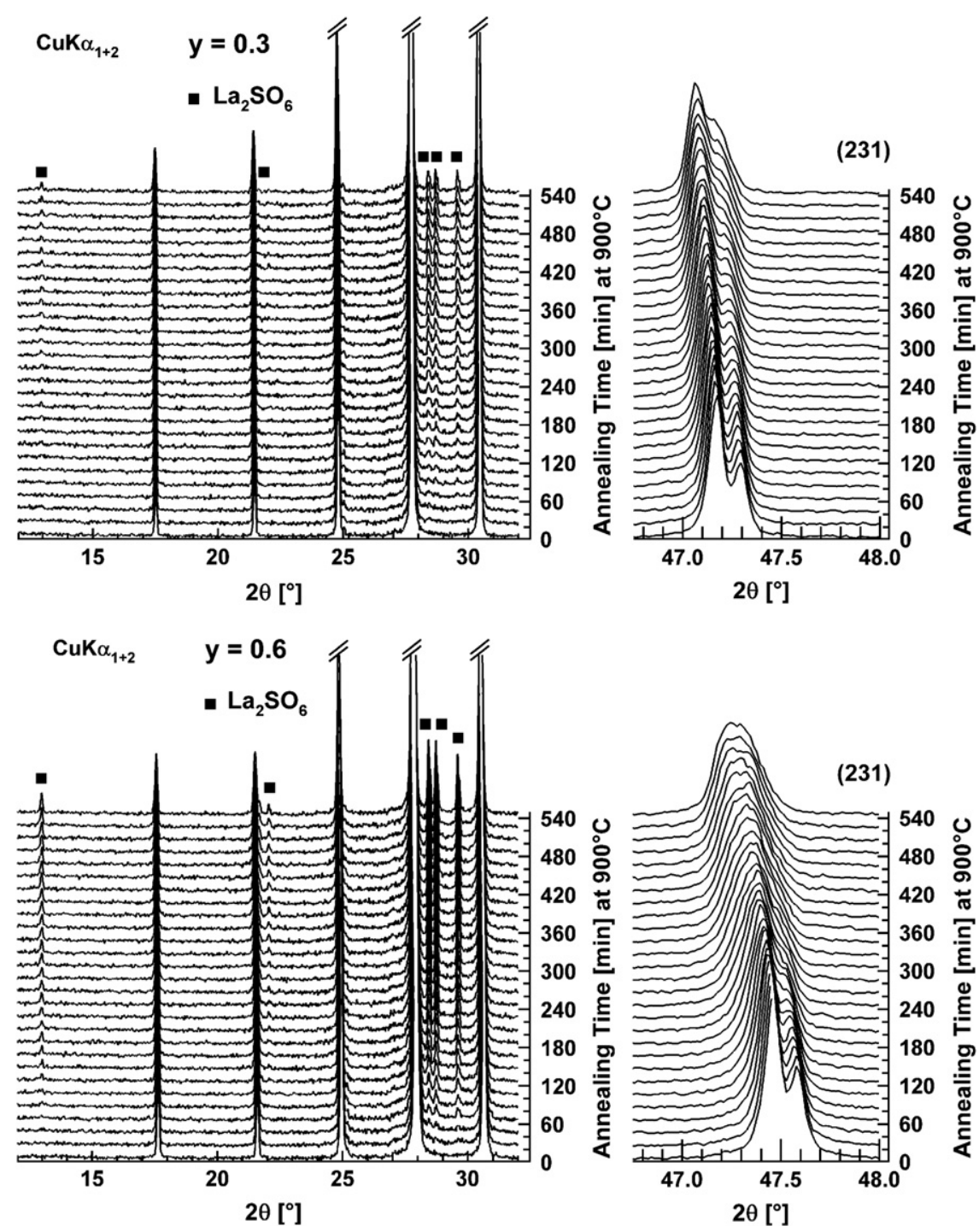

Fig. 6. (Left) Time evolution of the X-ray diffraction patterns of $\beta-\mathrm{La}_{2} \mathrm{Mo}_{1.7} \mathrm{~S}_{0.3} \mathrm{O}_{9}$ and $\beta-\mathrm{La}_{2} \mathrm{Mo}_{1.4} \mathrm{~S}_{0.6} \mathrm{O}_{9}$ raw powder samples during annealing at $900{ }^{\circ} \mathrm{C}$ in air (heating rate of $\left.10{ }^{\circ} \mathrm{C} / \mathrm{min}\right)$. (Right) Progressive shift and broadening of the (231) cubic reflection line $\left(\mathrm{CuK \alpha _{1+2 }}\right)$ of the $\beta$ - $\mathrm{La}_{2} \mathrm{Mo}_{2} \mathrm{O}_{9}$-type phase resulting from the sulfur depletion with the annealing time.

[31]. It originates from the distortive expansion of the framework built up from anti-tetrahedral $\left[01(\mathrm{La}, \mathrm{Bi})_{3} \mathrm{Mo}\right]$ units. Since hexavalent sulfur cation is much smaller than $\mathrm{Mo}^{6+}$, the way the cationic framework expands as the temperature increases is certainly affected by this substitution. Temperature-controlled X-ray powder diffraction was performed at first to probe the thermal stability of the high temperature $\beta$ form along the $\beta-\mathrm{La}_{2} \mathrm{Mo}_{2-y} \mathrm{~S}_{y} \mathrm{O}_{9}$ series and then to determine the thermal cell volume expansion for each composition. As shown in Fig. 7 for the two end specimens of our series, $\beta-\mathrm{La}_{2} \mathrm{Mo}_{1.9} \mathrm{~S}_{0.1} \mathrm{O}_{9}$ and $\beta-\mathrm{La}_{2} \mathrm{Mo}_{1.4} \mathrm{~S}_{0.6} \mathrm{O}_{9}$, the thermal evolution of the (231) cubic diffraction peak, the most sensitive to monoclinic distortion of the $\beta$-form, did not exhibit any splitting of diffraction peaks, as would be caused by a release of topological metastability (successive $\beta$-metastable $\alpha \alpha$ and $\alpha / \beta$ transitions in the temperature range $450-580^{\circ} \mathrm{C}$ ) [20]. Furthermore, no trace of impurity was detected on heating up to $845^{\circ} \mathrm{C}$, all samples remaining pure whatever the composition. Thus, the $\beta$ form of all sulfur-substituted LAMOX is stable from room temperature (RT) to $845^{\circ} \mathrm{C}$. Thereby, for each composition, the unit cell volume was obtained from Le Bail fit of the diffraction pattern in a cubic cell with the space group $P 2{ }_{1} 3$ (no. 198). Fig. 8a displays the thermal evolution of the cell volume for all compositions. As observed for cubic members of the $\beta-\mathrm{La}_{2-x} \mathrm{Eu}_{x} \mathrm{Mo}_{2} \mathrm{O}_{9}(x=0.2-0.4)$ [20] series, a characteristic increase of cell volume above $400{ }^{\circ} \mathrm{C}$, compared to its linear expansion at lower temperature, is clearly observed for $y=0.1$, 0.2 and 0.3 samples. The magnitude of this deviation from linearity within the $\beta-\mathrm{La}_{2} \mathrm{Mo}_{2-y} \mathrm{~S}_{y} \mathrm{O}_{9}$ series tends to be less pronounced when the sulfur content $y$ is higher. The temperature, at which the deviation occurs, increases with the sulfur content $y$, as shown in Fig. 8b. No deviation is noticed for the end composition $y=0.6$ of the series, the volume expansion being linear in the whole thermal range RT- $845^{\circ} \mathrm{C}$. An evidence of this change is given by the decrease upon sulfur substitution of the relative volume expansion $\left[V_{845}{ }^{\circ} \mathrm{C}-V_{25}{ }^{\circ} \mathrm{C}\right] / V_{25}{ }^{\circ} \mathrm{C}$ reported in Fig. $8 \mathrm{~b}$. As shown in this figure, a reduction in relative expansion of $\approx-0.8 \%$ occurs by substituting $5-30 \mathrm{~mol} \%$ of molybdenum by sulfur in $\beta$ - $\mathrm{La}_{2} \mathrm{Mo}_{2} \mathrm{O}_{9}$. This decrease in lattice expansion is, up to now, atypical upon isovalent substitution in $\mathrm{La}_{2} \mathrm{Mo}_{2} \mathrm{O}_{9}$ oxide. For instance, the relative volume expansion of $\beta-\mathrm{La}_{2-x} \mathrm{Eu}_{x} \mathrm{Mo}_{2} \mathrm{O}_{9}$ derivatives remains constant as the content $x$ increases, although trivalent europium is smaller than lanthanum ion. In the $\beta$ - $\mathrm{La}_{2} \mathrm{Mo}_{2-y} \mathrm{~S}_{y} \mathrm{O}_{9}$ series, this reduction of the relative volume expansion originates from the drop of size between $\mathrm{S}^{6+}$ and 

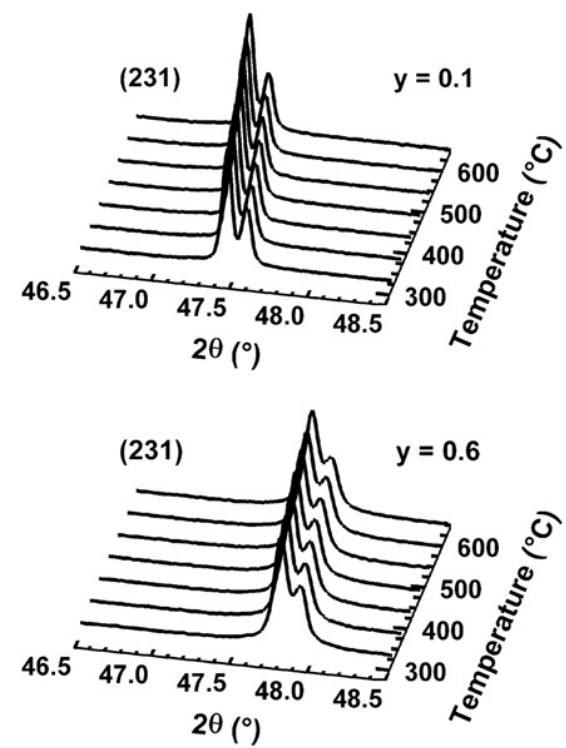

Fig. 7. Thermal evolution of the (231) cubic reflection line $\left(\mathrm{CuK \alpha _{1+2 }}\right)$ for $\beta-\mathrm{La}_{2} \mathrm{Mo}_{1.9} \mathrm{~S}_{0.1} \mathrm{O}_{9}$ and $\beta-\mathrm{La}_{2} \mathrm{Mo}_{1.4} \mathrm{~S}_{0.6} \mathrm{O}_{9}$ raw powder samples.
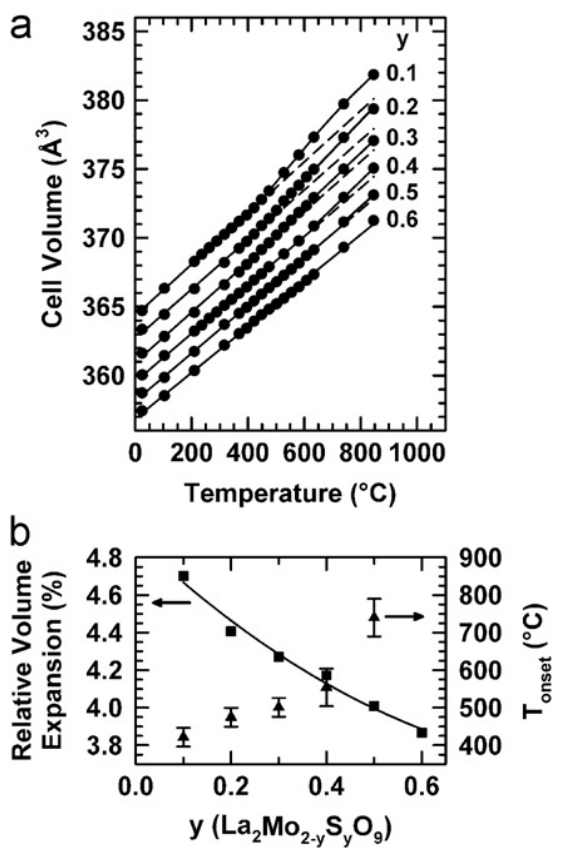

Fig. 8. (a) Temperature dependencies of the cubic cell volume of $\beta-\mathrm{La}_{2} \mathrm{Mo}_{2-y} \mathrm{~S}_{y} \mathrm{O}_{9}$ raw powder samples determined from temperature-controlled $\mathrm{X}$-ray diffraction data. (b) Evolution of the relative volume expansion $\left[V_{845}{ }^{\circ} \mathrm{C}-V_{25}{ }^{\circ} \mathrm{C}\right] / V_{25}{ }^{\circ} \mathrm{C}$ (squares) and of the temperature $T_{\text {onset }}$ (triangles) at which the change in Thermal Expansion Coefficient (TEC) occurs with the sulfur content $y$.

$\mathrm{Mo}^{6+}$ (relative variation $\approx-70.7 \%$ from the radii of ions in fourfold coordination tabulated by Shannon [26]) nearly nine times as large as the one between $\mathrm{Eu}^{3+}$ and $\mathrm{La}^{3+}$ (relative variation $\approx-8 \%$ whatever the coordination number).

\section{Effects of ball-milling and sintering on the phase stability}

The electrical measurements require the preparation of dense ceramic samples. High rate of densification can be achieved from a prior reduction of powder particle size by ball-milling before its shaping into pellet and the sintering for several hours at the highest temperature for which the sample remains stable. From TG analyses, it has been noticed that the decomposition of sulfursubstituted LAMOX powders starts above $900{ }^{\circ} \mathrm{C}$. However, no sintering for several hours can be performed at $900{ }^{\circ} \mathrm{C}$ since these powders decompose after few minutes $(20 \mathrm{~min}$ and $40 \mathrm{~min}$ for $y=0.3$ and 0.6 , respectively) under isothermal condition at this temperature. Raw powders being pure after the final annealing for $12 \mathrm{~h}$ at $850{ }^{\circ} \mathrm{C}$, these conditions were selected for sintering the pellet samples of ball-milled powders. Because of sulfur substitution of molybdenum greatly lowers the stability of lanthanum molybdate, ball milling of $\beta-\mathrm{La}_{2} \mathrm{Mo}_{2-y} \mathrm{~S}_{y} \mathrm{O}_{9}$ raw powders might have an incidence on this stability. In order to check it, we have performed two types of analysis by X-ray diffraction on several compositions of the series. At first, the phase purity of ball-milled powders before and after being air-annealed at $850{ }^{\circ} \mathrm{C}$ for $12 \mathrm{~h}$ (heating/cooling rates of $5{ }^{\circ} \mathrm{C} / \mathrm{min}$ ) was checked at room temperature. Our attention was focussed on the $\left[27-32^{\circ}\right]$ scattering angle range of the pattern where the most intense diffraction peaks of the decomposition products $\mathrm{La}_{2} \mathrm{MoO}_{6}$ or $\mathrm{La}_{2} \mathrm{SO}_{6}$ are located. A very high counting time was used for this kind of data collection (see details in experimental section). The aim of the second analysis is to probe by temperature-controlled X-ray diffraction the thermal stability of pellet $(\approx 13 \mathrm{~mm}$ diameter in diameter, $\approx 0.8 \mathrm{~mm}$ in thickness) after its sintering at $850{ }^{\circ} \mathrm{C}$ for $12 \mathrm{~h}$ (sample shaping detailed in experimental section). The diffractograms are shown together in Figs. 9 and 10.

\section{Ball-milled powders}

While the powders of $\beta-\mathrm{La}_{2} \mathrm{Mo}_{1.9} \mathrm{~S}_{0.1} \mathrm{O}_{9}$ and $\beta-\mathrm{La}_{2} \mathrm{Mo}_{1.8} \mathrm{~S}_{0.2} \mathrm{O}_{9}$ remain pure after ball-milling, three small peaks of the $\mathrm{La}_{2} \mathrm{SO}_{6}$ type phase are evidenced for ball-milled specimens $y=0.5$ and 0.6 and are very diffuse for $y=0.3$ (Fig. 9a). This behavior indicates that ball-milling can affect the stability of the phase leading to decomposition, as earlier observed in alloys [32,33] for instance. This decomposition during mechanical milling can originate either from the increase of the internal stresses and of the concentration of point defects, from the warming of the particle after its impact with balls loosing partially their mechanical energy or from a combination of both phenomena.

When ball-milled powder of $\beta-\mathrm{La}_{2} \mathrm{Mo}_{1.4} \mathrm{~S}_{0.6} \mathrm{O}_{9}$ is annealed at $850{ }^{\circ} \mathrm{C}$ for $12 \mathrm{~h}$, the exsolution of the $\mathrm{La}_{2} \mathrm{SO}_{6}$ type phase increases in magnitude without destabilizing the cubic $\beta$-form this time (Fig. 9b). This figure also shows that the annealing at $850{ }^{\circ} \mathrm{C}$ of $\beta$ - $\mathrm{La}_{2} \mathrm{Mo}_{1.9} \mathrm{~S}_{0.1} \mathrm{O}_{9}$ and $\beta-\mathrm{La}_{2} \mathrm{Mo}_{1.8} \mathrm{~S}_{0.2} \mathrm{O}_{9}$ ball-milled powders leads to their decomposition into $\mathrm{La}_{2} \mathrm{MoO}_{6}$ and $\mathrm{La}_{2} \mathrm{SO}_{6}$ type phases, respectively. Ball-milling was used to reduce particle size of $\mathrm{La}_{2} \mathrm{Mo}_{2} \mathrm{O}_{9}$ powder prior to sintering and no decomposition has ever been observed [34] $\left(\mathrm{La}_{2} \mathrm{Mo}_{2} \mathrm{O}_{9}\right.$ starts to incongruently melt only at $1354{ }^{\circ} \mathrm{C}$ [35]). As shown for $\mathrm{Al}_{2}\left(\mathrm{SO}_{4}\right)_{3}$ [36], a reduction of grain size by mechanical milling is likely to involve a thermal decomposition of ball-milled powders at a lower temperature than that reported for raw powders because of shorter diffusion length of ions in particles of a smaller size. Whatever the impurity $\mathrm{La}_{2} \mathrm{SO}_{6}$ or $\mathrm{La}_{2} \mathrm{MoO}_{6}$ formed according to Eq. (1) or (2), both partial decompositions imply the existence of different concentration gradients between grains of the LAMOX phase, in addition to the above impurity. In spite of same ball-milling conditions, Fig. 9b shows that the peak intensity of the $\mathrm{La}_{2} \mathrm{SO}_{6}$ type phase in ballmilled and annealed powders has a non-linear evolution with $y$ for $y$ ranging from 0.2 to 0.6 contrary to what has been observed for the thermal decomposition of raw powders according to Eq. (1).

\section{Pellets}

Even if the three small peaks of the $\mathrm{La}_{2} \mathrm{SO}_{6}$ type phase are very diffuse for $y=0.3$, they are clearly detected for specimens $y=0.4$ 

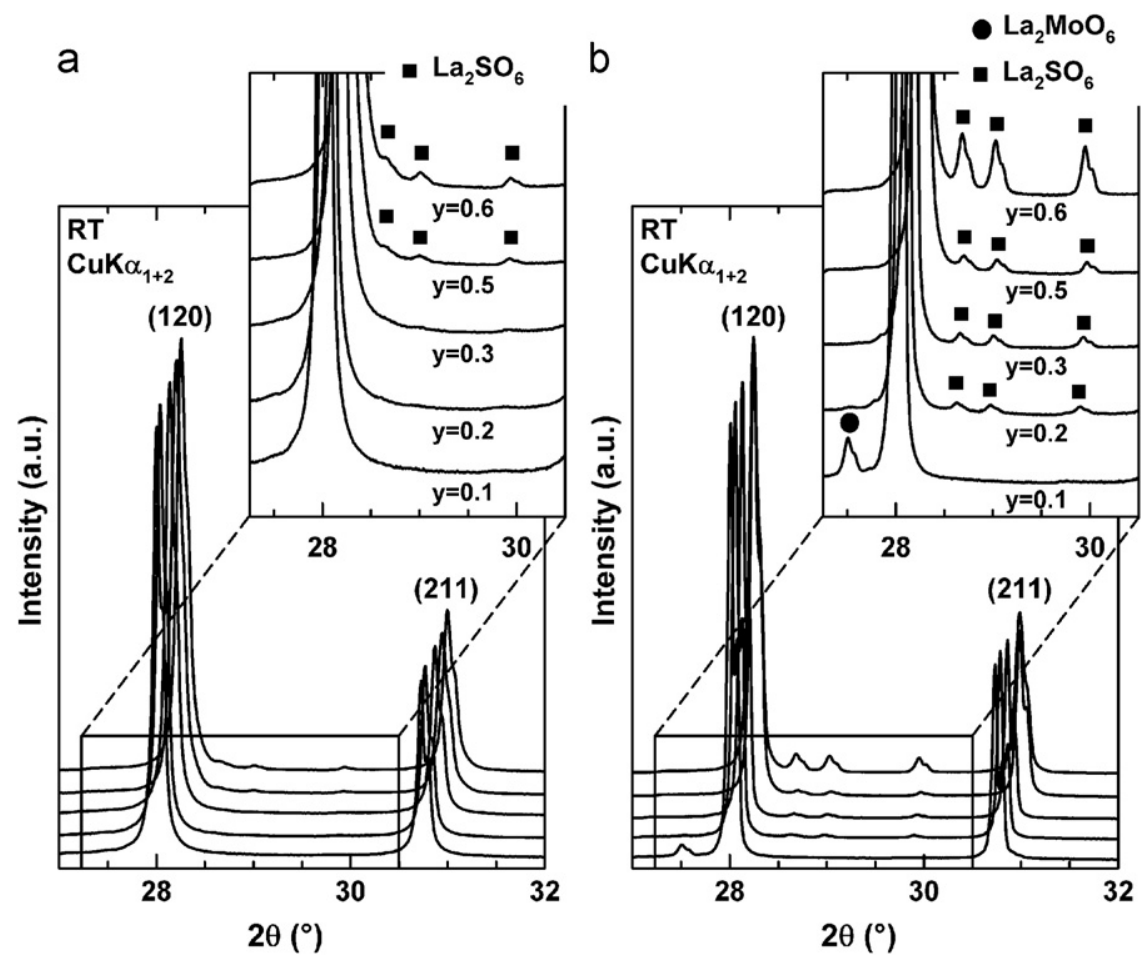

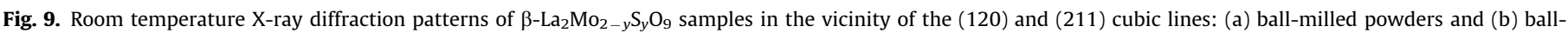
milled powders annealed at $850{ }^{\circ} \mathrm{C}$ for $12 \mathrm{~h}$.

and 0.6 in Fig. 10. The diffractogram collected on $\beta-\mathrm{La}_{2} \mathrm{Mo}_{1.9} \mathrm{~S}_{0.1} \mathrm{O}_{9}$ at room temperature shows that the compaction into pellet does not prevent a decomposition of the ball milled powder to occur during the sintering. However, in Fig. 10, no broadening or/and shift of the (231) cubic line of the $\beta-\mathrm{La}_{2} \mathrm{Mo}_{2} \mathrm{O}_{9}$ type phase and no evolution of the peak intensity of the $\mathrm{La}_{2} \mathrm{SO}_{6}$ type phase within $\beta$ - $\mathrm{La}_{2} \mathrm{Mo}_{1.6} \mathrm{~S}_{0.4} \mathrm{O}_{9}$ and $\beta-\mathrm{La}_{2} \mathrm{Mo}_{1.4} \mathrm{~S}_{0.6} \mathrm{O}_{9}$ pellets are noticed as the temperature increases. The cubic $\beta$-form being preserved, it indicates that the decomposition taking place during the milling/sintering process remains small in magnitude and does not evolve upon next heating.

\section{Transport property}

We have carried out impedance spectroscopy measurements on pellets issued from the sintering at $850{ }^{\circ} \mathrm{C}$ of ball milled powders. Pellets $(\approx 4.7-5.0 \mathrm{~mm}$ in diameter and $\approx 2.7-3.0 \mathrm{~mm}$ in thickness) were obtained with a relative density (with respect to the theoretical absolute value calculated from X-ray diffraction data) decreasing linearly from $97(1) \%$ to $79(1) \%$ upon substitution as the sulfur content $y$ increases (Fig. 11). The complex impedance spectra of $\mathrm{La}_{2} \mathrm{Mo}_{1.9} \mathrm{~S}_{0.1} \mathrm{O}_{9}$ and $\mathrm{La}_{2} \mathrm{Mo}_{1.4} \mathrm{~S}_{0.6} \mathrm{O}_{9}$ specimens recorded at $380{ }^{\circ} \mathrm{C}$ are presented in Fig. 12 . As shown in the Nyquist plot of the complex impedance spectrum for $\mathrm{La}_{2} \mathrm{Mo}_{1.4} \mathrm{~S}_{0.6} \mathrm{O}_{9}$ sample (Fig. 12a), two distinct semicircles in the frequency range $10^{6}$ $10^{2} \mathrm{~Hz}$ and a small arc at lower frequency are noticed. These three contributions ( 2 semicircles +1 arc) were satisfactorily fitted with a series combination of three $R / / C P E$ elements (where $R$ is a pure resistance and CPE is a Constant Phase Element) and a wires inductance $L 1$ by using the "calc-modulus" data weighting mode (each data points weight is normalized by its magnitude) of the Z-view 3.0a software [37]. In Fig. 12a, an apparent single semicircle at high frequency and a small arc at low frequency are noted in the Nyquist plot for $\mathrm{La}_{2} \mathrm{Mo}_{1.9} \mathrm{~S}_{0.1} \mathrm{O}_{9}$ sample. Two equivalent circuits built from a series combination of (two $R / / C P E$ elements and a wires inductance $L 1$ ) and (three $R / /$ CPE elements and a wires inductance L1) were then tested for fitting of frequency response data of $\mathrm{La}_{2} \mathrm{Mo}_{1.9} \mathrm{~S}_{0.1} \mathrm{O}_{9}$ sample. The calculated complex impedance spectra are shown for both models in Fig. S1 (Electronic supplementary data). The best electrical equivalent circuit, having the lowest goodness of fit $\chi^{2}$ and the lowest Weighted Sum of Squares, corresponds to the one built from a series combination of three $R / / C P E$ elements and a wires inductance $L 1$, which was already used for $\mathrm{La}_{2} \mathrm{Mo}_{1.4} \mathrm{~S}_{0.6} \mathrm{O}_{9}$ specimen. Thereby, the whole complex impedance spectra were then fitted with this equivalent circuit whatever the $\beta-\mathrm{La}_{2} \mathrm{Mo}_{2-y} \mathrm{~S}_{y} \mathrm{O}_{9}$ sample considered. On the basis of the values of capacitance obtained by fitting:

- the first semicircle ( $\approx 8.5 \times 10^{-12}-1.2-10^{-11} \mathrm{~F}$ ) was assigned to the bulk (B) response,

- the second semicircle $\left(\approx 2.3 \times 10^{-10}-4.1 \times 10^{-8} \mathrm{~F}\right)$ is characteristic of a grain boundary (GB) contribution,

- the small arc $\left(\approx 1 \times 10^{-4} \mathrm{~F}\right)$ at the low-frequency side was ascribed to the polarization phenomenon associated with oxide ion conduction between the sample and the platinum electrodes.

As shown in the previous section, a segregation of secondary phase $\left(\mathrm{La}_{2} \mathrm{SO}_{6}\right.$ or $\left.\mathrm{La}_{2} \mathrm{MoO}_{6}\right)$ from the LAMOX phase occurred either during ball-milling of raw powders or later, when ballmilled powders were annealed at $850{ }^{\circ} \mathrm{C}$. No ionic conduction was reported in the literature for these impurities. Since the exsolved phase is located at the boundary of grains together with pores, both segregation and porosity involve blocking effects on the electrical properties of $\beta-\mathrm{La}_{2} \mathrm{Mo}_{2-y} \mathrm{~S}_{y} \mathrm{O}_{9}$ pellets. In Fig. $12 \mathrm{~b}$, the grain boundary resistance $R_{G B}$ determined at $380{ }^{\circ} \mathrm{C}$ exponentially increases as the sulfur content $y$ increases along the series. This evolution of $R_{G B}$ reflects that both the porosity (Fig. 11) and the segregation (Fig. 9) increase with $y$. For the less dense 

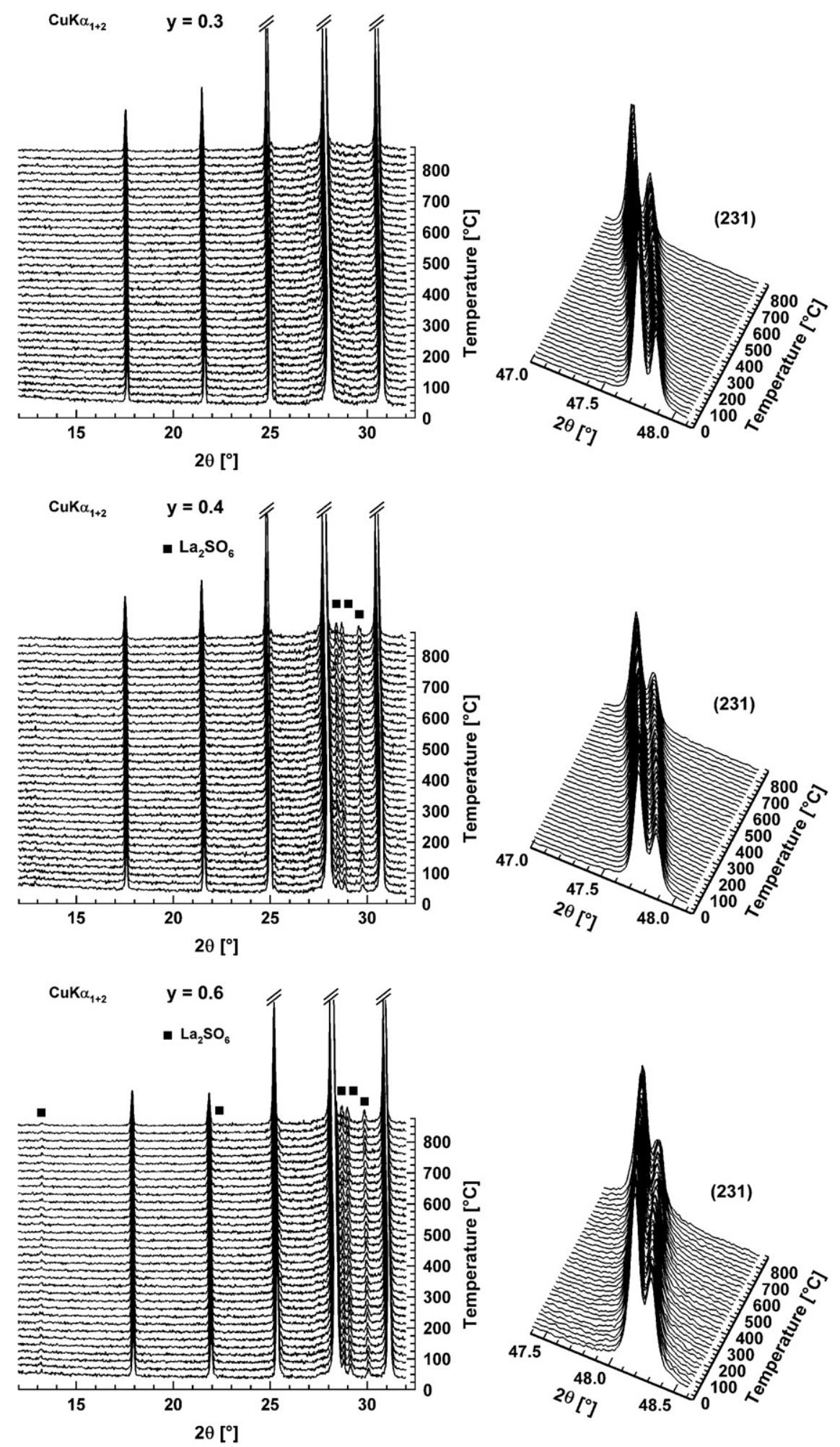

Fig. 10. Thermal evolution of the diffraction patterns upon heating of different $\beta$-La $\mathrm{Mo}_{2-} \mathrm{S}_{y} \mathrm{O}_{9}$ pellets of ball-milled powders sintered at $850{ }^{\circ} \mathrm{C}$ for $12 \mathrm{~h}$.

$\mathrm{La}_{2} \mathrm{Mo}_{1.4} \mathrm{~S}_{0.6} \mathrm{O}_{9}$ pellet containing the larger amount of secondary $\mathrm{La}_{2} \mathrm{SO}_{6}$ phase, the resistance $R_{G B}$ is more than twice higher than the bulk resistance. In order to measure the incidence of sulfur substitution on ionic transport, the bulk conductance was calculated from the resistance taking into account the geometric factor of the pellet. Temperature dependencies of the bulk conductance are presented in Fig. 13.
At low temperature, the conductance of all the samples exhibits a conventional Arrhenius-type behavior with similar activation energies (Fig. 13). In $\beta-\mathrm{La}_{2} \mathrm{Mo}_{1.9} \mathrm{~S}_{0.1} \mathrm{O}_{9}$ and $\beta-\mathrm{La}_{2}$ $\mathrm{Mo}_{1.8} \mathrm{~S}_{0.2} \mathrm{O}_{9}$ samples, a departure from the Arrhenius-type behavior is noted below $1000 / T \approx 1.5 \mathrm{~K}^{-1}$ and $\approx 1.45 \mathrm{~K}^{-1}$ with an increase and then a levelling off at higher temperature. In the high temperature conduction regime above $\approx 400{ }^{\circ} \mathrm{C}$, the conductance 


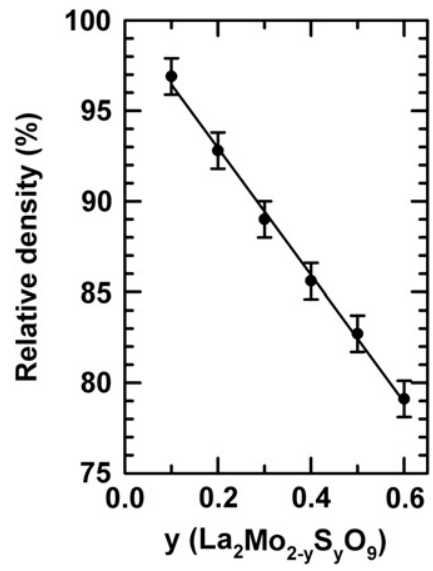

Fig. 11. Evolution of the relative density of $\beta-\mathrm{La}_{2} \mathrm{Mo}_{2-y} \mathrm{~S}_{y} \mathrm{O}_{9}$ ceramic samples with the sulfur content $y$.
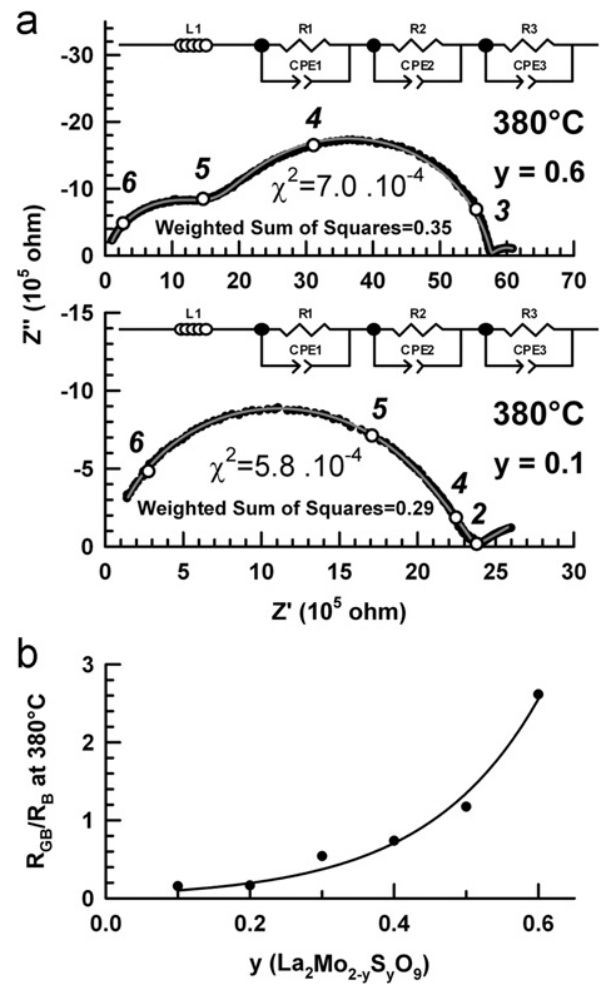

Fig. 12. (a) Nyquist representation of observed complex impedance spectra (dots) collected on ceramics of $\beta-\mathrm{La}_{2} \mathrm{Mo}_{1.9} \mathrm{~S}_{0.1} \mathrm{O}_{9}$ and $\beta-\mathrm{La}_{2} \mathrm{Mo}_{1.4} \mathrm{~S}_{0.6} \mathrm{O}_{9}$ in air at $380{ }^{\circ} \mathrm{C}$ (numbers correspond to frequency logarithms) and comparison with the spectra calculated (gray line) from the equivalent electrical circuit displayed in inset (b) Evolution of the $R_{G B} / R_{B}$ ratio as a function of the sulfur content $y$ in the $\beta$ - $\mathrm{La}_{2} \mathrm{Mo}_{2-y} \mathrm{~S}_{y} \mathrm{O}_{9}$ series $\left(R_{G B}\right.$ and $R_{B}$ are the grain boundaries and bulk resistances deduced from the fit).

is always higher than values calculated from the extension to high temperature of the Arrhenius law describing the conductance behavior at low temperature. Such a thermal evolution of the conductance is characteristic of $\beta$-stabilized LAMOX compounds [20]. A weakening of the inflexion of the curvature is noted as the sulfur content increases from $y=0.1$ to 0.2 . For $y \geq 0.3$ compositions, increasing the sulfur content involves a progressive change in the high temperature part of the conductance curve from a positive to a negative deviation from the Arrhenius regime at low temperature. At $725^{\circ} \mathrm{C}$, a large decrease by about one order of magnitude of the conductance relative to pure $\mathrm{La}_{2} \mathrm{Mo}_{2} \mathrm{O}_{9}$ is noticed for the $y=0.6$ pellet sample. The decrease of the sulfur content in the LAMOX phase down to $y=0.1$ reduces this difference in conductance without never attaining the value measured for the parent compound $\mathrm{La}_{2} \mathrm{Mo}_{2} \mathrm{O}_{9}$ (Fig. 13).

In $\beta$-stabilized LAMOX compounds, we have recently shown that the singular increase of the conductance above 400$450{ }^{\circ} \mathrm{C}$ would be due to the migration of $\mathrm{O} 1$ oxide ions towards nearest neighboring vacancies at $\mathrm{O} 2$ or $\mathrm{O} 3$ sites thanks to the distortion change and to the extra increase of the thermal vibrations of its anti-tetrahedral [ $\left.\mathrm{La}_{3} \mathrm{Mo}\right]$ coordination. Above $400{ }^{\circ} \mathrm{C}$, the distortive thermal expansion of the cationic framework built up from anti-tetrahedral $\left[01 \mathrm{La}_{3}(\mathrm{Mo}, \mathrm{S})\right]$ units decreases in magnitude as the sulfur content $y$ increases in the $\beta$ - $\mathrm{La}_{2} \mathrm{Mo}_{2-y} \mathrm{~S}_{y} \mathrm{O}_{9}$ series (Fig. 8). The larger covalent character of the sulfur-oxygen bond relative to that of molybdenum-oxygen bond might be responsible of the low ability of anti-tetrahedral $\left[\mathrm{La}_{3} \mathrm{~S}\right]$ coordination of $\mathrm{O} 1$ oxide ion to distort and to assist its migration. Thereby, the higher the sulfur content $y$, the lower the overall mobility of oxide ions at high temperature. This assumption is consistent with the progressive change from a positive to a negative deviation from Arrhenius-type behavior of the conductance above $400{ }^{\circ} \mathrm{C}$ as the sulfur content $y$ increases along the series.

\section{Summary and conclusion}

The solid solution $\mathrm{La}_{2} \mathrm{Mo}_{2-y} \mathrm{~S}_{y} \mathrm{O}_{9}$ was studied with the aim to determine its extent and thermal stability. All compositions crystallize in the high temperature cubic $\beta$-form of $\mathrm{La}_{2} \mathrm{Mo}_{2} \mathrm{O}_{9}$ for a sulfur content $y$ greater than or equal to 0.1 . Temperaturecontrolled X-ray diffraction and thermogravimetric analyses have shown that the thermal decomposition of $\mathrm{La}_{2} \mathrm{Mo}_{2-y} \mathrm{~S}_{y} \mathrm{O}_{9}$ raw powders occurs in two steps. Heating above $900{ }^{\circ} \mathrm{C}$, a sulfur depletion to the benefit of molybdenum in $\mathrm{La}_{2} \mathrm{Mo}_{2-y} \mathrm{~S}_{y} \mathrm{O}_{9}$ raw powders leads to the formation of $\mathrm{La}_{2} \mathrm{SO}_{6}$. The exsolved $\mathrm{La}_{2} \mathrm{SO}_{6}$ phase decomposing into $\mathrm{La}_{2} \mathrm{O}_{3}$ at higher temperature in turn reacts with the sulfur-depleted $\mathrm{La}_{2} \mathrm{Mo}_{2} \mathrm{O}_{9}$ phase to form $\mathrm{La}_{2} \mathrm{MoO}_{6}$. The present study reveals that depending on the substitution rate $y$, such a sulfur depletion can occur during ball-milling of raw powders or during post-annealing of ball-milled powders at $850^{\circ} \mathrm{C}$. Preparing dense and pure ceramic samples of sulfursubstituted LAMOX was then difficult because of this low stability. One possible way to get dense ceramic samples exempted of impurity would be to synthesize fine raw powders via a "chimie douce" route allowing their sintering at a temperature lower than $850^{\circ} \mathrm{C}$. As an illustration, the sintering temperature $(3 \mathrm{~h}$ at $1000{ }^{\circ} \mathrm{C}$ ) of $\mathrm{La}_{2} \mathrm{Mo}_{2} \mathrm{O}_{9}$ powder synthesized by solid state reaction and then ball milled has been lowered by $200{ }^{\circ} \mathrm{C}$ when powder was prepared via the pyrolysis of polyacrylate [38] or polyaspartate [39] salt precursors $\left(5 \mathrm{~h}\right.$ at $\left.800{ }^{\circ} \mathrm{C}\right)$. A similar behavior has also been shown earlier for $\mathrm{Ce}_{1-x} \mathrm{Sm}_{x} \mathrm{O}_{2-x / 2}$ [40] or $\mathrm{Ce}_{1-x} \mathrm{Y}_{x} \mathrm{O}_{2-x / 2}$ [41] oxides prepared through co-precipitation or sol-gel route, respectively.

The present study has also shown that the isovalent substitution of molybdenum by sulfur tends to restrict in magnitude or even to suppress above $400{ }^{\circ} \mathrm{C}$ the distortive thermal expansion of the cubic $\beta$-type structure, thus strongly decreasing the conductance. It has been proposed that the larger covalent character of the sulfuroxygen bond relative to that of molybdenum-oxygen bond might be responsible for the low ability of the cationic framework to distort and thus to increase the overall mobility of the oxide ions at high temperature. Direct investigation of the dynamics of the polyhedron through temperature-controlled Raman spectroscopy could provide experimental evidence of such mechanism. 


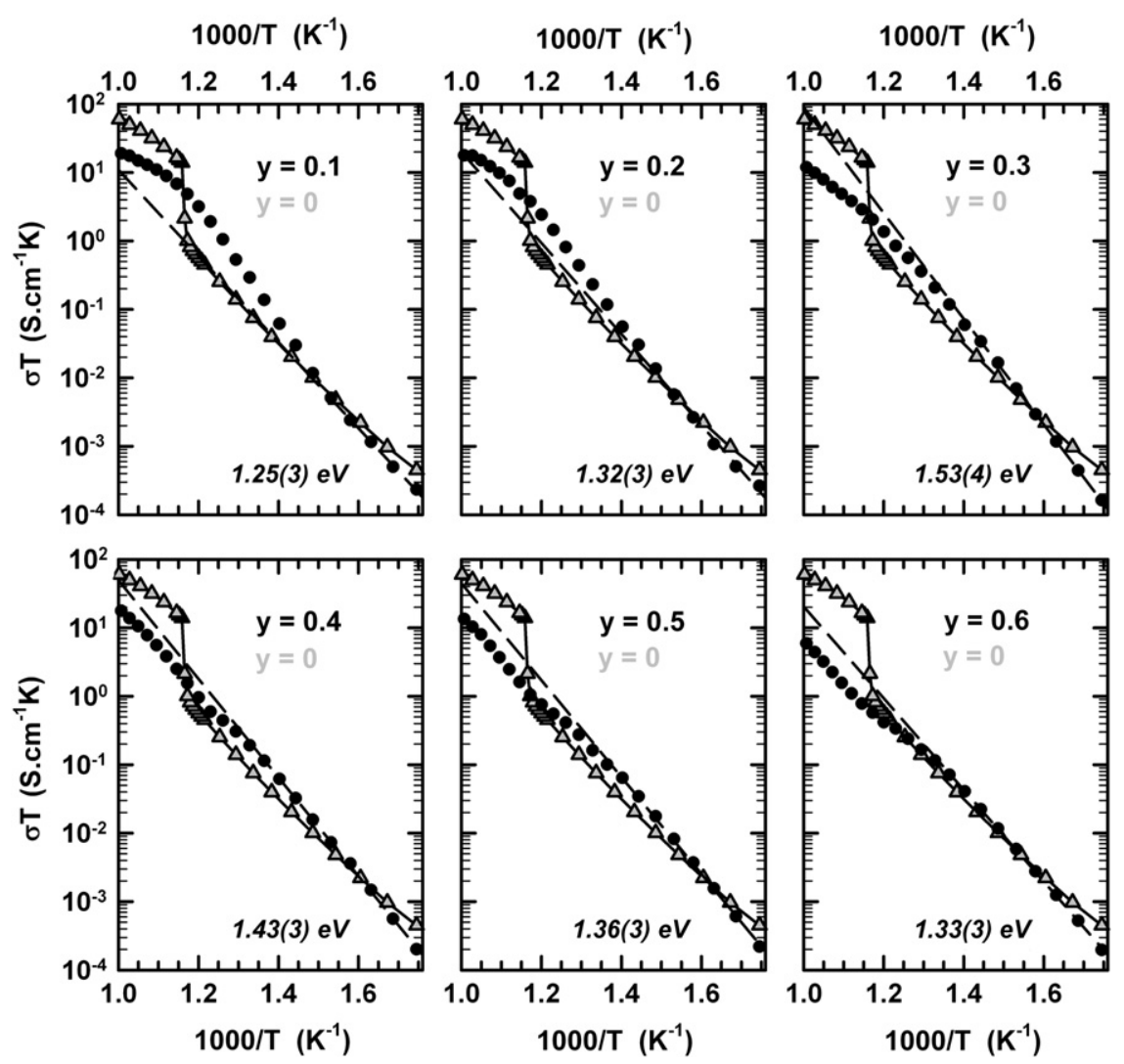

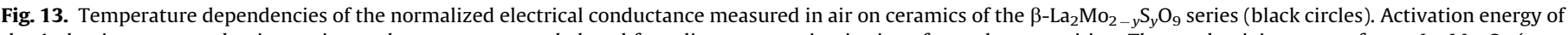

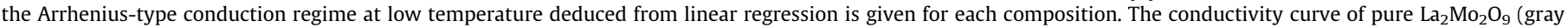
triangles) is added for reference (pellet sintered $3 \mathrm{~h}$ at $1000{ }^{\circ} \mathrm{C}$, relative density $96(1) \%$ of theoretical density).

\section{References}

[1] P. Lacorre, F. Goutenoire, O. Bohnke, R. Retoux, Y. Laligant, Nature 404 (2000) $856-858$.

[2] F. Goutenoire, O. Isnard, R. Retoux, P. Lacorre, Chem. Mater. 12 (2000) 2575-2580.

[3] X.P. Wang, Q.F. Fang, Z.S. Li, G.G. Zhang, Z.G. Yi, Appl. Phys. Lett. 81 (2002) 3434-3436.

[4] A. Subramania, T. Saradha, S. Muzhumathi, J. Power Sources 167 (2007) 319-324.

[5] S. Georges, F. Goutenoire, F. Altorfer, D. Sheptyakov, F. Fauth, E. Suard, P. Lacorre, Solid State Ionics 161 (2003) 231-241.

[6] D. Marrero-Lopez, J. Canales-Vazquez, W.Z. Zhou, J.T.S. Irvine, P. Nunez, J. Solid State Chem. 179 (2006) 278-288.

[7] D. Marrero-Lopez, P. Nunez, M. Abril, V. Lavin, U.R. Rodriguez-Mendoza, V.D. Rodriguez, J. Non-Cryst. Solids 345-346 (2004) 377-381.

[8] C. Tealdi, G. Chiodelli, L. Malavasi, G. Flor, J. Mater. Chem. 14 (2004) 3553-3557.

[9] X.P. Wang, Z.J. Cheng, Q.F. Fang, Solid State Ionics 176 (2005) 761-765.

[10] D. Marrero-Lopez, D. Perez-Coll, J.C. Ruiz-Morales, J. Canales-Vazquez, M.C. Martin-Sedeno, P. Nunez, Electrochim. Acta 52 (2007) 5219-5231.

[11] G. Corbel, Y. Laligant, F. Goutenoire, E. Suard, P. Lacorre, Chem. Mater. 17 (2005) 4678-4684.

[12] J.A. Collado, M.A.G. Aranda, A. Cabeza, P. Olivera-Pastor, S. Bruque, J. Solid State Chem. 167 (2002) 80-85.

[13] V.I. Voronkova, E.P. Kharitonova, A.E. Krasil'nikova, Crystallogr. Rep. 55 (2010) 276-282.

[14] S. Basu, P.S. Devi, H.S. Maiti, J. Electrochem. Soc. 152 (2005) A2143-A2147.

[15] Z.S. Khadasheva, N.U. Venskovskii, M.G. Safronenko, A.V. Mosunov, E.D. Politova, S.Y. Stefanovich, Inorg. Mater. 38 (2002) 1168-1171.

[16] A. Selmi, C. Galven, G. Corbel, P. Lacorre, Dalton Trans. 39 (2010) 93-102.
[17] A. Selmi, G. Corbel, P. Lacorre, Solid State Ionics 177 (2006) 3051-3055.

[18] A. Selmi, G. Corbel, S. Kodjikian, V. Voronkova, E. Kharitonova, P. Lacorre, Eur. J. Inorg. Chem. (2008) 1813-1821.

[19] G. Corbel, P. Durand, P. Lacorre, J. Solid State Chem. 182 (2009) 1009-1016

[20] G. Corbel, E. Chevereau, S. Kodjikian, P. Lacorre, Inorg. Chem. 46 (2007) 6395-6404.

[21] F. Goutenoire, O. Isnard, E. Suard, O. Bohnke, Y. Laligant, R. Retoux, P. Lacorre J. Mater. Chem. 11 (2001) 119-124.

[22] M.W. Nathans, W.W. Wendlandt, J. Inorg. Nucl. Chem. 24 (1962) 869-879.

[23] G. Corbel, S. Mestiri, P. Lacorre, Solid State Sci. 7 (2005) 1216-1224.

[24] A. Le Bail, H. Duroy, J.L. Fourquet, Mater. Res. Bull. 23 (1988) 447-452.

[25] J. Rodriguez Carvajal, Physica B 192 (1993) 55-69.

[26] R.D. Shannon, Acta Crystallogr. A32 (1976) 751-767.

[27] PDF-4+2009; The International Centre for Diffraction Data (ICDD), 12 Campus Boulevard, Newtown Square, Pennsylvania 19073-3273, USA.

[28] M. Castellanos, A.R. West, J. Chem. Soc.-Faraday Trans. I 76 (1980) 2159-2169.

[29] J.S. Xue, M.R. Antonio, L. Soderholm, Chem. Mater. 7 (1995) 333-340.

[30] S. Zhukov, A. Yatsenko, V. Chernyshev, V. Trunov, E. Tserkovnaya, O. Antson, J. Hölsä, P. Baulés, H. Schenk, Mater. Res. Bull. 32 (1997) 43-50.

[31] G. Corbel, E. Suard, P. Lacorre, Chem. Mater. 23 (2011) 1288-1298.

[32] K.B. Gerasimov, A.A. Gusev, E.Y. Ivanov, V.V. Boldyrev, J. Mater. Sci. 26 (1991) 2495-2500.

[33] T. Alonso, H. Yang, Y. Liu, P.G. McCormick, Appl. Phys. Lett. 60 (1992) 833-834.

[34] S. Georges, F. Goutenoire, P. Lacorre, M.C. Steil, J. Eur. Ceram. Soc. 25 (2005) 3619-3627.

[35] J.P. Fournier, J. Fournier, R. Kohlmuller, Bull. Soc. Chim. Fr. 12 (1970) 4277-4283.

[36] M. Ghasri-Khouzani, M. Meratian, M. Panjepour, J. Alloys Compd. 472 (2009) 535-539.

[37] D. Johnson, Scribner Associates Inc., 150 E. Connecticut Avenue, Southern Pines, NC, USA.

[38] A. Subramania, T. Saradha, S. Muzhumathi, Mater. Res. Bull. 43 (2008) 1153-1159.

[39] A. Subramania, T. Saradha, S. Muzhumathi, J. Alloys Compd. 456 (2008) 234-238.

[40] W. Huang, P. Shuk, M. Greenblatt, Solid State Ionics 100 (1997) 23-27.

[41] Y.F. Gu, G. Li, G.Y. Meng, D.K. Peng, Mater. Res. Bull. 35 (2000) 297-304. 